\title{
The Development or Exacerbation of an Autoimmune Disorder Associated with SARS-CoV-2 infection: a Systematic Review of Case Reports
}

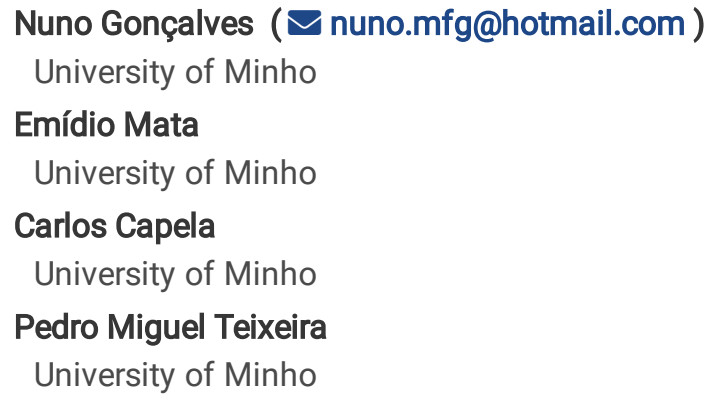

\section{Research Article}

Keywords: Autoimmune diseases, Autoimmunity, Coronavirus Disease 2019, COVID 19, SARS CoV 2

Posted Date: April 22nd, 2021

DOI: https://doi.org/10.21203/rs.3.rs-344958/v1

License: (c) (i) This work is licensed under a Creative Commons Attribution 4.0 International License. Read Full License 


\section{Abstract}

Background: Infections have long been studied as environmental triggers of autoimmunity. Previous associations between coronavirus and autoimmune disorders make severe acute respiratory syndrome coronavirus 2 (SARS-CoV-2), a novel coronavirus identified in December 2019, a potential candidate for autoimmune disorder development. Indeed, an increasing number of these cases have been reported prompting a characterization and summarization of existing evidence.

Objectives: This review aims to characterize and summarize case reports documenting the development or exacerbation of an autoimmune disorders associated with SARS-CoV-2 infection.

Methods: A bibliographic search of Embase was performed from inception to July 2020. Studies included reported the development or exacerbation of an autoimmune disorder associated with SARS-CoV-2 infection. Quality was judge using Joanna Briggs Institute Critical Appraisal Checklist for Case Reports and piloted forms were used for data collection. Data were summarized using descriptive statistics and narrative synthesis.

Results: From 304 entries, 85 different cases were included, 41\%-99\% with good appraisal across quality domains. Sixty-two (72.9\%) patients had no previous autoimmune disorder and 70 (82.4\%) developed it De novo, the most frequent being Guillain-Barré syndrome and multisystem inflammatory syndrome in children. Eighteen (21.2\%) cases of autoimmune disorders, mostly in remission, exacerbated. Organ-specific disease was found in 57 (67.1\%) and systemic in 28. Disease affection was categorized into groups, the most frequent being neurological $(36 ; 42.4 \%)$, vasculitis $(19 ; 22.4 \%)$, blood $(15 ; 17.6 \%)$, and connectivitis/systemic lupus erythematosus/antiphospholipid syndrome (6; 7.1\%). The median coronavirus disease-2019 to De novo autoimmune disorder latency was 11 days $(\mathrm{IQR}=5.75-16)$.

Conclusions: Although, as a systematic review of case reports, this study cannot verify causality, it provides support for further studies on the relationship between SARS-CoV-2 and autoimmune disorders. Furthermore, it delivers a characterization and summarization of existing reports making it a resource for clinicians to be aware of possible autoimmune disorder complications while taking care of their SARS-CoV-2 infected patients.

\section{Background}

Autoimmunity is an immune response directed against a self-antigen and its presence is a defining characteristic of an autoimmune disorder (AD). In the US, the estimated prevalence of ADs is 7.6-9.4\% [1]. Infections are one of the most well-studied environmental triggers for autoimmunity [2-4], possibly through "molecular mimicry", epitope spreading, "bystander activation", and cryptic antigens processing and presentation [2]. Infections have also been associated with AD exacerbations, possibly via the same mechanisms [5].

In December 2019, a cluster of pneumonia cases was identified in Wuhan, China [6, 7], subsequently found to be caused by severe acute respiratory syndrome coronavirus 2 (SARS-CoV-2) [8, 9]. The infection is addresses as coronavirus disease 2019 (COVID-19) [10] and has already spread worldwide, leading to a global pandemic. Although most coronavirus infections are mild, two strains, SARS-CoV and Middle East respiratory syndrome coronavirus (MERS-CoV), have led to outbreaks and are associated with severe disease [11]. Infection by SARS-CoV-2 ranges from asymptomatic to critical condition and has already claimed millions of lives.

As SARS-CoV-2 infection has taken global proportions affecting a myriad of diverse patients, and has also been known to provoke hyperstimulation of the immune system through cytokine storm [12] and prolonged viral shedding [13], it is a potential candidate for AD association. Indeed, reports of ADs following COVID-19 have already been described (e.g. Kawasaki disease-like multisystem inflammatory syndrome in children (MIS-C)) [14, 15]. Additionally, SARS-CoV-2 forms a sister clave with SARS-CoV [9] (based on phylogeny, taxonomy, and established practice) which has cross-reaction with lung epithelial cells as a potential mechanism of pathogenesis $[16,17]$. Moreover, MERS-CoV has also been associated with ADs such as Guillain-Barré syndrome (GBS) [18] and possibly immune thrombocytopenia [19]. Because of these findings and the increasing number of case reports, a characterization and summarization of existing evidence on the association of ADs and SARS-CoV-2 infection is necessary.

Although case reports cannot verify causality between the infection and ADs, it can identify unrecognized associations, generate hypotheses for subsequent studies and warn clinicians of possible complications. For these purposes, a systematic review of case 
reports was performed documenting the development of an $A D$, related complications and autoimmune comorbidity exacerbation associated with the SARS-CoV-2 infection.

\section{Methods}

This systematic review followed the recommendations of the PRISMA statement [20].

\section{Eligibility criteria}

Studies were eligible when they reported a case of SARS-CoV-2 infection and the development of an AD, related complication, or exacerbation of a preexisting autoimmune comorbidity with a temporal relation with COVID-19. Studies with no explicitly stated SARS-CoV-2 infection diagnosis or with autoimmune comorbidities without exacerbations were excluded. The study designs considered eligible were any case report/series where the patient's case information was provided separately. Studies where information about a case could not be distinguished from another were excluded.

\section{Information sources and search}

A bibliographic search was performed in Embase on 21/07/2020. The search strategy consisted of terms related to COVID-19 or SARS-CoV-2 AND AD (including autoimmunity-related terms and specific ADs) AND Case report or Case series. Each term was subsequently extended using synonyms and the subject headings functions of Embase (complete query in Additional file 1).

\section{Study selection}

Resulting entries were organized using EndNote X9.2. Duplicates were removed using the automated function. Title and abstract screening was carried out by two independent reviewers (NG and EM) and any entry which met eligibility criteria, where abstracts could not be obtained, or had insufficient information to access eligibility were considered for full-text review. Full text was then independently reviewed by the same two reviewers. A third researcher (CC) resolved disagreements. Publications not written in English or Portuguese were translated to English using Google Translate.

\section{Data collection process and data items}

A data extraction form was piloted with 15 random eligible entries. One reviewer (NG) extracted the data regarding studies' characteristics (author, publication date, methodology, country, number of cases), participants' characteristics (age, sex, comorbidities, AD comorbidities status and treatment), and case's characteristics (clinical features by area, COVID-19 confirmation test and treatment, laboratory, imaging, and other tests requested and findings, AD diagnosed and treatment, COVID-19 to AD latency, complications, hospitalization and intensive care unit (ICU) admission, patient outcome). Articles reporting on the same patient were counted as one case and combined to obtain more data.

\section{Quality assessment}

Quality was assessed independently by two reviewers (NG and EM) using the Joanna Briggs Institute (JBI) Critical Appraisal Checklist for Case Reports [21]. Disagreements were resolved with a third researcher (CC). Each of the eight domains was given an answer of: yes (information present and clearly described), unclear (information present but not clearly described), no (information not present), and not applicable.

\section{Data synthesis and analysis}

A summary of the paper's publication, authorship, study design, patient's characteristics, and main findings was provided through detailed tables. The ADs retrieved for this review were diagnosis collected from the studies. When a diagnosis was not explicit, the 
most probable cause was determined by reviewing the case's characteristics. A narrative synthesis was performed, and data were summarized using descriptive statistics: for categorical variables frequencies and percentages; for continuous variables means and standard deviations (SD), and medians and interquartile ranges (IQR) for skewed distributions (assessed with Shapiro-Wilk test).

\section{Results}

\section{Study selection}

The PRISMA flowchart details the selection process and the reasons for full-text exclusion (Figure 1). In summary, out of 304 entries 69 regarding 85 cases were considered eligible. Two articles reporting on the same patient were merged and therefore counted together.

\section{Study characteristics}

Main case characteristics are summarized in Table 1 and Additional file 2 and 3 . Studies comprised 6 case series and 63 case reports published from January to June 2020, spanning 15 countries.

\section{Quality appraisal}

Good appraisal ranged from $41 \%$ to $99 \%$ across quality domains (Figure 2). Although most cases clearly reported the patient's demographic characteristics, current clinical condition, diagnostic tests and methods, and summarized takeaway lessons, they lacked key elements of good reporting: intervention or treatment protocols, post-intervention clinical condition, adverse or unanticipated events, and patient's history.

\section{Demographical characteristics and clinical findings}

General population and case characteristics are summarized in Table 2. The patients' age did not follow a normal distribution with a greater number of older patients (median: 53 (32-63 IQR) years) and ranged from 5 to 83 years old. Forty-five patients were male and 40 female (Table 2). Comorbidities were present in $45(64,7 \%)$ cases, the most common: hypertension (24/45), diabetes mellitus (11/45), cerebrovascular disease (5/45), obesity (4/45), and psoriasis (4/45).

Clinical findings are detailed in Additional file 3. Most patients developed respiratory (72; 84.7\%), mostly persistent cough, and nonspecific symptoms (68; 80.0\%), mainly fever. Additionally, nervous (48;56.5\%), gastrointestinal $(27 ; 31.8 \%)$, and skin $(21 ; 24.7 \%)$ clinical findings were also among the most common.

\section{COVID-19-related characteristics}

Nasopharyngeal and/or oropharyngeal swab real-time reverse transcription polymerase chain reaction (rRT-PCR) was used in 78 patients wielding 12 negative results (later confirmed through Immunoglobulin G (IgG) antibody serum testing). One patient was diagnosed only by IgG antibody serum testing and in six it was not clear which confirmation test was used. Additionally, one had positive rRT-PCR on cerebrospinal fluid (CSF) for SARS-CoV-2.

Seventy-nine (92.9\%) cases requested general laboratory measurements, $66(77.6 \%)$ inflammatory markers, 46 (54.1\%) hemostasis system parameters and $43(50.6 \%)$ immunological markers. Overall, the most requested laboratory tests were complete blood count (75.3\%), c-reactive protein (63.5\%), d-dimers (45.9\%), ferritin (34.1\%) and lactate dehydrogenase (LDH) (32.9\%). The most common findings were high c-reactive protein, lymphocytopenia, high d-dimers, thrombocytopenia, leukocytosis, high ferritin, high LDH and anemia (Table 2).

Bilateral disease on chest computerized tomography (CT) and x-ray was found in 57 (67.1\%) patients, while unilateral disease in six (7.1\%), and nine (10.6\%) had normal results. The most common findings were bilateral ground-glass opacities, bilateral pulmonary infiltrates, and diffused consolidations (Table 2). 
Twenty-six patients (30.6\%) received no COVID-19 treatment. Among the remaining, hydroxychloroquine was the most common. Forty patients $(47.1 \%)$ required supportive therapies: intubation $(24 ; 28.2 \%)$, mechanical ventilator support $(19 ; 22.4 \%)$ and high flow oxygen therapy $(14 ; 16.5 \%)$. Antibiotics, mainly azithromycin, and antivirals, mostly lopinavir/ritonavir, favipiravir, and/or oseltamivir were also common. Some patients received other therapies, primarily comprising of anticoagulant and immunosuppressive therapies (mostly corticosteroids) (Table 2).

While $52(61.2 \%)$ patients had no complication (other than AD), the remaining presented mostly cardiovascular complications (22/33) and secondary infection (10/33). Almost all cases (83; 97.6\%) required hospitalization with 35 (41.2\%) admitted to the ICU. Mean hospital stay was 16.76 (10.18 SD) days (information not available in 39 cases). Favorable outcome (recovery or hospital discharge) was reported in 55 cases (23 male; mean age: 46.61 years) and death in nine (8 male; mean age: 66.3 years) (Table 2).

\section{AD-related characteristics}

Sixty-two patients (72.9\%) had no previous AD. Eighteen (21.2\%), mostly in remission (13/18), experienced an exacerbation (the most frequent: psoriasis, myasthenia gravis, antiphospholipid syndrome (APS)/systemic lupus erythematosus (SLE), Crohn's disease, immune thrombocytopenic purpura (ITP), multiple sclerosis), while 70 (82.4\%) developed De novo AD (three had De novo AD plus exacerbation) (Table 2). The most common were GBS, MIS-C, ITP, acute disseminated encephalomyelitis (ADEM), autoimmune meningoencephalitis, APS and autoimmune hemolytic anemia (AlHA). A total of 22 different ADs developed, while 12 distinct AD exacerbations were found.

ADs were categorized into organ-specific disease (57; 67.1\%): neurological, blood, inflammatory bowel disease (IBD), skin, endocrinological, and ophthalmological; and systemic disease (28; 32.9\%): vasculitis, connectivitis/SLE-APS, arthritis, endocrinological. Median COVID-19 to De novo AD latency was 12 (6-16 IQR) days (Table 2). Mean COVID-19 to AD exacerbation latency was 6.56 (8.14 SD) days.

\section{Organ-specific disease}

\section{Neurologic-related AD}

Median age was 54 (45.25-61.75 IQR), 16 were female and 30 had no previous AD. While four were exacerbations (two multiple sclerosis and two myasthenia gravis previously in remission), the majority were De novo ADs: GBS (14;38.9\%), ADEM (6; 16.7\%), autoimmune meningoencephalitis (6; 16.7\%), CNS vasculitis $(2 ; 5.6 \%)$, anti-MOG associated encephalomyelitis $(1 ; 2.8 \%)$, anti-NMDA receptor encephalitis $(1 ; 2.8 \%)$, non-classified encephalitis $(1 ; 2.8 \%)$, and oculomotor nerve palsy $(1 ; 2.8 \%)$. Three subtypes of GBS were reported: four acute inflammatory demyelinating polyneuropathy, three acute motor and sensory axonal neuropathy, and three Miller-Fisher syndrome. Median COVID-19 to De novo AD latency was 12 (7-15 IQR) days (Table 2).

The most common laboratory finding was CSF high protein level: five cases with pleocytosis and five without. Five patients had high CSF IgG, one patient had positive anti-MOG antibody, another both anti-NMDA receptor and anti-cardiolipin antibodies, and another anti-ganglioside antibodies (Asialo GM1). Of 24 brain magnetic resonance imaging (MRI) requested, 12 were normal, with white matter lesions the most common feature found in the remainders. In 12, out of 14 cases with GBS, nerve conduction studies aided the diagnosis (Table 2).

Most patients received intravenous immunoglobulin (IVIG), corticosteroids, plasmapheresis, and plasma exchange, while 3 received no AD treatment. Four patients required supportive therapy (intubation and mechanical ventilator support) for GBS and myasthenia gravis exacerbation. Nevertheless, supportive therapy for COVID-19 was needed in 21. Mean hospitalization time was 19.2 (11.24 SD) days and death was reported in five (Table 2).

\section{Blood-related AD}

Median age was 53 (38-65 IQR), nine were female and 10 had no previous AD. Two had ITP exacerbations (previously in remission), and 13 experienced De novo ADs: ITP $(8 ; 53.3 \%)$, AlHA (4; 26.7\%) (one cold agglutinin disease and one warm agglutinin disease), and autoimmune thrombotic thrombocytopenic purpura (1;6.7\%). Median COVID-19 to De novo AD latency was 10 (6.25-15.75 IQR) days (Table 2). 
The most common laboratory finding was thrombocytopenia and anemia. Other virus screens were negative (Epstein-Barr virus, hepatitis virus, Human Immunodeficiency Virus (HIV), Cytomegalovirus). Four patients had positive direct Coombs test, two with high cold agglutinin titers, one of these also with positive antinuclear antibodies (ANA). One case reported low ADAMTS-13 activity and positive ADAMTS-13 inhibitory antibodies, another antiplatelet antibodies, and another positive (albeit weak) anti-platelet factor 4/heparin antibodies. Two cases performed bone marrow aspirate, revealing normal cellularity with increased megakaryocyte count (Table 2). Chest and brain CT revealed two pulmonary embolism and two intracerebral hemorrhages.

All patients received $A D$ treatment, the majority with corticosteroids, IVIG, platelet transfusions and red blood cell transfusions. For COVID-19, four required no treatment and only three required ICU admission. Mean hospitalization time was 19.85 (11.16 SD) days and one death was reported (Table 2).

\section{Other organ-specific ADs}

Three cases had an exacerbation of IBD: one ulcerative colitis (UC) and one Crohn's disease previously in remission, and one active Crohn's disease. The Crohn's disease patients also presented De novo IgA vasculitis and Kawasaki disease. Age ranged from 14 to 26 years old. The UC case was a pregnant woman with proctitis, Disease Activity Index score of 3 , and active chronic inflammation on biopsies, treated with methylprednisolone and cyclosporine, and ultimately undergoing spontaneous abortion. Abdominal CT and MRI enterography found ileitis in both Crohn's disease cases. One (previously in remission) also had perianal abscess and fistula requiring drainage, antibiotics, and infliximab, while the other received the regular adalimumab treatment (Table 1).

Concerning skin-related ADs, two exacerbations of psoriasis (one in remission) and one De novo livedo reticularis were reported. The psoriasis cases occurred in a 73-year-old male 14 days after COVID-19 onset, and in a 71-year-old female 4 days after, neither receiving AD treatment. The livedo reticularis case occurred in a 57-year-old male with high d-dimers and positive ANAs, 8 days after COVID-19 onset, and treated with low-molecular-weight heparin (Table 1).

For endocrinological-related ADs, one diabetes mellitus type 1 exacerbation in the form of diabetic ketoacidosis, and one autoimmune hypothyroidism exacerbation was reported. The diabetic ketoacidosis case occurred in a 60-year-old male 5 days after COVID-19 onset, complicating with secondary bacterial infection and pulmonary embolism. He was treated with insulin and required ICU admission. The autoimmune hypothyroidism exacerbation received no treatment and occurred concurrent with De novo ITP in a 65-year-old female with elevated thyroid peroxidase antibodies, 11 days after COVID-19 onset (Table 1).

An ophthalmological-related AD befell an 11-year-old male with left retinal vasculitis on ocular fundus examination, negative autoimmune panel, and chilblains (Table 1).

\section{Systemic disease}

\section{Vasculitis-related AD}

Median age was 13 (9-36 IQR), eight were female, and 15 had no previous AD. One had an exacerbation of anti-neutrophil cytoplasmic antibodies (ANCA) associated vasculitis in the form of glomerulonephritis and 18 experienced De novo ADs: MIS-C (11; $57.9 \%)$, cutaneous small-vessel vasculitis $(2 ; 10.5 \%)$, multisystem inflammatory syndrome in adults (MIS-A) $(1 ; 53 \%)$, Kawasaki disease $(1 ; 53 \%)$, immunoglobulin A (IgA) vasculitis $(1 ; 53 \%)$, non-classified vasculitis $(1 ; 53 \%)$, and gallbladder vasculitis $(1 ; 53 \%)$. Median COVID-19 to De novo AD latency was 5 (0-13 IQR) days (Table 2). When MIS-C and Kawasaki disease are not counted, median age was 59 (25-83 IQR), two out of seven were female, and median COVID-19 to De novo AD latency was 13 (7.5-37 IQR) days. As previously mentioned, two cases had, concurrent with De novo AD, an exacerbation of Crohn's disease. Gastrointestinal (15; $78.9 \%$ ) (mostly abdominal pain) and skin $(13 ; 68.4 \%)$ findings were common clinical findings. Nine $(47.4 \%)$ patients had no complications while the remaining experienced mainly cardiogenic shock $(8 ; 42.1 \%)$, and acute kidney injury $(6 ; 31.6 \%)$.

Fourteen (73.7\%) cases had hemostasis system-related findings: high d-dimers, fibrinogen, INR, and prothrombin time; 16 (84.2\%) inflammatory markers: high c-reactive protein, procalcitonin, ferritin, lactate dehydrogenase, and erythrocyte sedimentation rate; 6 (31.6\%) increased serum interleukin 6, interleukin 8, and/or tumor necrosis factor-a; and 11 (57.9\%) liver markers: high alanine aminotransferase, aspartate aminotransferase and gamma-glutamyl transferase, direct hyperbilirubinemia, and hypoalbuminemia. Seven (36.8\%) cases reported high troponins and one (5.3\%) elevated myoglobin. The IgA vasculitis case had high complement C4 
and serum IgA, and one cutaneous small-vessel vasculitis case had anti-cardiolipin antibodies. The ANCA-associated vasculitis exacerbation case was cytoplasmic-ANCA positive, and the MIS-A case presented positive ANAs, anti-Ro/SSA and low complement $\mathrm{C} 3$ and C4. From 14 heart ultrasounds requested, seven reported depressed left ventricular systolic function, five coronary artery dilatation, and three pericardial effusion. Abdominal CT exams showed bowel inflammation (ileitis and/or colitis) in four cases. Three patients underwent skin lesion biopsy, all wielding leukocytoclastic vasculitis as the major finding (Table 2).

Most patients received antibiotic prophylaxis, IVIG, corticosteroids, immunosuppressive therapy (tocilizumab, anakinra, or cyclophosphamide), and acetylsalicylic acid, while two received no AD treatment. Most patients required ICU admission with one Kawasaki disease, and seven MIS-C patients requiring rescue and supportive therapy for cardiogenic shock. Nevertheless, most required no COVID-19 treatment. Death was reported in two and mean hospitalization time was 14.92 (10.48 SD) days (Table 2).

\section{Connectivitis/SLE-APS-related AD}

Median age was 67 (50-69.25 IQR) and three were female. Four cases had no previous AD and developed De novo APS, and two had APS/SLE (previously in remission) and APS exacerbations. Median COVID-19 to De novo AD latency was 25.5 (12-45 IQR) days (Table 2).

The De novo APS cases had positive anti-beta-2-glycoprotein I and anti-cardiolipin antibodies, and high d-dimers, while three had high fibrinogen, prothrombin and partial thromboplastin time, and one high fibrin degradation products (Table 2). Patients had multiple cerebral $(5 ; 83.3 \%)$ and bilateral cerebellar $(3 ; 50.0 \%)$ infarctions on brain CT. On doppler ultrasound one patient had bilateral jugular venous thrombi. One De novo APS case complicated with index finger dry gangrene and another with two digits and lower limbs bilateral ischemia.

Three cases received AD treatment, one with acetylsalicylic acid, low-molecular-weight heparin and plasma exchange, and two with IVIG, one of which with eltrombopag, platelet transfusions and prednisone. Five required COVID-19 treatment, three with supportive therapy. Mean hospitalization time was 21.17 (18.76 SD) days with four ICU admissions and one reported death (APS exacerbation) (Table 2).

\section{Other systemic AD}

For Arthritis-related ADs, one ankylosing spondylitis exacerbation (previously in remission) and one De novo non-classified arthritis were reported. The ankylosing spondylitis case occurred in a 53-year-old female 22 days after COVID-19 onset with normal brain MRI and nerve conduction studies, and was treated with etanercept. The non-classified arthritis case occurred in a 57-year-old male 20 days after COVID-19 onset with negative ANAs, rheumatoid factor and anti-cyclic citrullinated peptide antibodies, and the synovial fluid was crystal-free on polarized microscopic examination (Table 1).

One endocrinological-related AD case, a 32-year-old female with autoimmune polyglandular syndrome type 1, presented with hypoparathyroidism exacerbation with low serum calcium, and was treated with calcitriol and calcium supplementation. She required ICU admission for COVID-19 (Table 1).

\section{Discussion}

This review describes 22 different De novo ADs and 12 distinct AD exacerbations associated with SARS-CoV-2 infection.

As AD cases in children ( $<18$ years) have been reported following SARS-CoV- 2 infection, most notably MIS-C [14, 15], one could argue the existence of more associations. In this regard, entry age was not restricted, and besides MIS-C and Kawasaki disease, AlHA and retinal vasculitis were also found. The reported higher prevalence of older patients, cardiovascular risk factor comorbidity, and cardiovascular disease could be explained by their added risk of severe COVID-19 and hospital admission [91, 92], in line with this review's inpatient cohort. Contrary to the literature on AD gender differences [93], there were more males than females found (9:8).

COVID-19 was predominantly diagnosed through rRT-PCR, the present recommendation. Laboratory and radiologic findings were similar to those found in the literature $[7,91,94]$. Treatment was heterogeneous, reflecting the immaturity of the disease knowledge. Most were treated with hydroxychloroquine and antibiotics (predominantly azithromycin), the recommendation at the time. Additionally, similar to another review [94], a reduced number of patients received no treatment for COVID-19, and intubation, 
mechanical ventilator support, and mortality were higher than the general population, suggesting greater disease severity, which, again, may relate to the number of hospitalizations in this cohort. Furthermore, more patients than expected required ICU admission which may be explained by the association of AD complications.

Most cases had no previous AD and, ultimately, all developed one, which supports the causal relationship hypothesis. Furthermore, most patients with $A D$ comorbidity exacerbations were previously in remission.

The majority presented with neurological affection. Neurological complications have been common in COVID-19 [95-98]. The dissemination to the nervous system through the cribriform plate, olfactory bulb [99] and virus damaged capillary endothelium [100] have been hypothesized for such association. When referring to a neurological AD, other mechanisms such as the hyperinflammatory state leading to blood-brain barrier disruption, extensive tissue damage, and epitome exposure, could instead contribute to its development, as only one case reported positive CSF rRT-PCR for SARS-CoV-2 and specific antibody driven subtypes of autoimmune encephalitis were found: anti-MOG associated encephalomyelitis and anti-NMDA receptor encephalitis. The most common neurological AD found was GBS, which is a typical post respiratory or gastrointestinal infection disorder [101, 102]. Among other pathogens [101], MERS-CoV was associated with GBS [18]. The median COVID-19 to De novo AD latency of 12 days and mean hospitalization time of 19.2 days resembles the 1-2 weeks latency and the 2-4 weeks peak clinical deficit reported in the literature $[101,102]$. Although the preceding pathogen infection is usually connected with one clinical phenotype [101], three subtypes were found. Another neurological AD found, ADEM, is already associated with viral infections. Although more common in pediatric age, all cases found were adults [103]. Though few patients required supportive therapy for neurological AD, downplaying its severity, it should be noted that many required it for COVID-19.

The majority of vasculitis found were MIS-C, a disorder similar to Kawasaki disease that has been connected with the rise of SARSCoV-2 cases [15]. As Kawasaki disease presumably develops in genetically susceptible hosts after exposure to a trigger, suspected to be an upper respiratory tract infection [104], a similar mechanism could be occurring here. Although predominantly having mild COVID-19, most cases required ICU admission and eight children (with MIS-C and Kawasaki disease) develop cardiogenic shock.

The most common blood-related AD was ITP. As secondary ITP has been associated with cross-reaction with HIV antigens, creating autoantibodies and immune complexes [105-107], the same might occur with SARS-CoV-2. However, although not always present [108], out of eight ITP cases, only two rendered positive antiplatelet antibodies, and COVID-19 has been associated with thrombocytopenia, the degree of which related to the severity of SARS-CoV-2 infection [109].

In the final major group, APS, four anti-beta-2-glycoprotein I and anti-cardiolipin antibody positive patients complicated with multiple thrombotic events. Though antiphospholipid antibodies can be present in acute infections, they usually present with low levels and are not associated with thrombotic events [110]. Infections are also suspected triggers as they preceded APS in many cases [111, 112].

\section{Limitations}

Even though good appraisal in several quality domains was seen across studies, key elements of good reporting were lacking, and 21 cases did not report an outcome. Likewise, other reviews shared the same findings [94]. A possible explanation might be the urgency to publish new information, as COVID-19 is a recently identified disease. This, however, may lead to a lack of important information that could further the knowledge of possible associations with ADs. Nevertheless, all cases were included as a way to find the most possible number of associations.

Although numerous associations between infections and ADs are described, the acute state of infection and hyperinflammatory state which occurs with COVID-19 could mimic the immunological findings of an AD. Since the reported autoimmune manifestations might encompass the immunological component of the infection, caution is warranted when interpreting the results. Nevertheless, a high suspicion rating is always necessary when considering an $A D$ diagnosis.

Furthermore, milder AD cases might not be represented due to publication bias as more severe cases are more likely to be published and diagnosed. 
Although a thorough search was done, using an expansive search query to be as inclusive as possible, methodological limitations are still present. First, only one database was used and, even though this review provides a look at the first image of the COVID-19 pandemic, it may have missed studies that were published since the search date. Additionally, despite using piloted forms and training to minimize inaccuracies, only one reviewer performed data extraction.

\section{Conclusions}

This systematic review provides a characterization and summarization of AD cases associated with SARS-CoV-2 infection. There are some findings that may suggest the existence of this relationship and although this study as a review of case reports cannot verify causality, it supports further studies and provides a resource for clinicians to be aware of possible AD complications of SARS-CoV-2 infected patients.

\section{Declarations}

\section{Availability of Supporting Data}

The data set supporting the results of this article is included within the article (and its additional files).

\section{Competing interests}

None of the authors have any financial or non-financial competing interests to disclose.

\section{Funding}

None.

\section{Author's contributions}

NG performed the screening, study selection, data collection, analysis, and interpretation, conceptualized and drafted the manuscript. EM performed screening and study selection, analyzed data, and contributed to the writing of the manuscript. CC aided in data analysis and interpretation and performed critical revision of the article. PMT contributed to conception and design of the work. All authors have reviewed and approved the manuscript for submission.

\section{Abbreviations}

AD: Autoimmune disorder; SARS-CoV-2: Severe acute respiratory syndrome coronavirus 2; COVID-19: Coronavirus disease 2019; MERS-CoV: Middle East respiratory syndrome coronavirus; MIS-C: Multisystem inflammatory syndrome in children; GBS: GuillainBarré syndrome; ICU: Intensive care unit; JBI: Joanna Briggs Institute; SD: Standard deviations; rRT-PCR: Real-time reverse transcription polymerase chain reaction; IgG: Immunoglobulin G; CSF: Cerebrospinal fluid; LDH: Lactate dehydrogenase; CT: Computerized tomography; APS: Antiphospholipid syndrome; SLE: Systemic lupus erythematosus; ITP: Immune thrombocytopenic purpura; ADEM: Acute disseminated encephalomyelitis; AlHA: Autoimmune hemolytic anemia; IBD: Inflammatory bowel disease; MRI: Magnetic resonance imaging; IVIG: Intravenous immunoglobulin; HIV: Human Immunodeficiency Virus; ANA: Antinuclear antibodies; UC: Ulcerative colitis; ANCA: Anti-neutrophil cytoplasmic antibodies; MIS-A: Multisystem inflammatory syndrome in adults; IgA: Immunoglobulin A

\section{Bibliography}

1. Cooper GS, Bynum ML, Somers ECJJoa: Recent insights in the epidemiology of autoimmune diseases: improved prevalence estimates and understanding of clustering of diseases. 2009, 33(3-4):197-207.

2. Ercolini A, Miller SDJC, Immunology E: The role of infections in autoimmune disease. 2009, 155(1):1-15. 
3. Marrack P, Kappler J, Kotzin BLJNm: Autoimmune disease: why and where it occurs. 2001, 7(8):899-905.

4. Wang L, Wang FS, Gershwin MEJJoim: Human autoimmune diseases: a comprehensive update. 2015, 278(4):369-395.

5. Kamradt T, Göggel R, Erb KJJTii: Induction, exacerbation and inhibition of allergic and autoimmune diseases by infection. 2005, 26(5):260-267.

6. Pneumonia of unknown cause-China. 2020 [https://www.who.int/csr/don/05-january-2020-pneumonia-of-unkown-causechina/en/]

7. Huang C, Wang Y, Li X, Ren L, Zhao J, Hu Y, Zhang L, Fan G, Xu J, Gu XJTI: Clinical features of patients infected with 2019 novel coronavirus in Wuhan, China. 2020, 395(10223):497-506.

8. Zhu N, Zhang D, Wang W, Li X, Yang B, Song J, Zhao X, Huang B, Shi W, Lu RJNEJoM: A novel coronavirus from patients with pneumonia in China, 2019. 2020.

9. Viruses CSGotICoTo: The species Severe acute respiratory syndrome-related coronavirus: classifying 2019-nCoV and naming it SARS-CoV-2. 2020, 5(4):536.

10. Organization WH: Naming the coronavirus disease (COVID-19) and the virus that causes it. In.; 2020.

11. Su S, Wong G, Shi W, Liu J, Lai AC, Zhou J, Liu W, Bi Y, Gao GFJTim: Epidemiology, genetic recombination, and pathogenesis of coronaviruses. 2016, 24(6):490-502.

12. Mehta P, McAuley DF, Brown M, Sanchez E, Tattersall RS, Manson JJ, Lancet HASCJ: COVID-19: consider cytokine storm syndromes and immunosuppression. 2020, 395(10229):1033.

13. Zhou F, Yu T, Du R, Fan G, Liu Y, Liu Z, Xiang J, Wang Y, Song B, Gu XJTI: Clinical course and risk factors for mortality of adult inpatients with COVID-19 in Wuhan, China: a retrospective cohort study. 2020.

14. Jones VG, Mills M, Suarez D, Hogan CA, Yeh D, Segal JB, Nguyen EL, Barsh GR, Maskatia S, Mathew RJHP: COVID-19 and Kawasaki disease: novel virus and novel case. 2020, 10(6):537-540.

15. Riphagen S, Gomez X, Gonzalez-Martinez C, Wilkinson N, Theocharis PJTL: Hyperinflammatory shock in children during COVID19 pandemic. 2020, 395(10237):1607-1608.

16. Lin Y-S, Lin C, Fang Y, Kuo Y-M, Liao P-C, Yeh T-M, Hwa K, Shieh C, Yen J, Wang HJC et al: Antibody to severe acute respiratory syndrome (SARS)-associated coronavirus spike protein domain 2 cross-reacts with lung epithelial cells and causes cytotoxicity. 2005, 141(3):500-508.

17. Lo AW, Tang NL, To KFJTJoPAJotPSoGB, Ireland: How the SARS coronavirus causes disease: host or organism? 2006, 208(2):142-151.

18. Kim J-E, Heo J-H, Kim H-o, Song S-h, Park S-S, Park T-H, Ahn J-Y, Kim M-K, Choi J-PJJoCN: Neurological complications during treatment of middle east respiratory syndrome. 2017, 13(3):227-233.

19. Arabi YM, Arifi AA, Balkhy HH, Najm H, Aldawood AS, Ghabashi A, Hawa H, Alothman A, Khaldi A, Al Raiy BJAoim: Clinical course and outcomes of critically ill patients with Middle East respiratory syndrome coronavirus infection. 2014, 160(6):389-397.

20. Moher D, Liberati A, Tetzlaff J, Altman DG, med PGJP: Preferred reporting items for systematic reviews and meta-analyses: the PRISMA statement. 2009, 6(7):e1000097.

21. Moola S, Munn Z, Tufanaru C, Aromataris E, Sears K, Sfetcu R, Currie M, Qureshi R, Mattis P, Lisy KJJBIRsMTJBI: Chapter 7: Systematic reviews of etiology and risk. 2017:2019-2005.

22. Sedaghat Z, Karimi N: Guillain Barre syndrome associated with COVID-19 infection: A case report. Journal of Clinical Neuroscience 2020.

23. Chiu JS, Lahoud-Rahme M, Schaffer D, Cohen A, Samuels-Kalow M: Kawasaki Disease Features and Myocarditis in a Patient with COVID-19. Pediatric Cardiology 2020.

24. Allez M, Denis B, Bouaziz JD, Battistella M, Zagdanski AM, Bayart J, Lazaridou I, Gatey C, Pillebout E, Chaix Baudier ML et al: Covid-19 related IgA vasculitis. Arthritis \& rheumatology (Hoboken, NJ) 2020.

25. Dolinger MT, Person H, Smith R, Jarchin L, Pittman N, Dubinsky MC, Lai J: Pediatric Crohn's Disease and Multisystem Inflammatory Syndrome in Children (MIS-C) and COVID-19 Treated with Infliximab. Journal of pediatric gastroenterology and nutrition 2020.

26. Ottaviani D, Boso F, Tranquillini E, Gapeni I, Pedrotti G, Cozzio S, Guarrera GM, Giometto B: Early Guillain-Barré syndrome in coronavirus disease 2019 (COVID-19): a case report from an Italian COVID-hospital. Neurological Sciences 2020, 41(6):1351- 
1354.

27. Scheidl E, Canseco DD, Hadji-Naumov A, Bereznai B: Guillain-Barré syndrome during SARS-CoV-2 pandemic: A case report and review of recent literature. Journal of the Peripheral Nervous System 2020, 25(2):204-207.

28. Parsons T, Banks S, Bae C, Gelber J, Alahmadi H, Tichauer M: COVID-19-associated acute disseminated encephalomyelitis (ADEM). Journal of Neurology 2020.

29. Zanin L, Saraceno G, Panciani PP, Renisi G, Signorini L, Migliorati K, Fontanella MM: SARS-CoV-2 can induce brain and spine demyelinating lesions. Acta Neurochirurgica 2020, 162(7):1491-1494.

30. Hanafi R, Roger PA, Perin B, Kuchcinski G, Deleval N, Dallery F, Michel D, Hacein-Bey L, Pruvo JP, Outteryck O et al: COVID-19 Neurologic Complication with CNS Vasculitis-Like Pattern. AJNR American journal of neuroradiology 2020.

31. Patil NR, Herc ES, Girgis M: Cold agglutinin disease and autoimmune hemolytic anemia with pulmonary embolism as a presentation of COVID-19 infection. Hematology/ Oncology and Stem Cell Therapy 2020.

32. Moeinzadeh F, Dezfouli M, Naimi A, Shahidi S, Moradi H: Newly Diagnosed Glomerulonephritis During COVID-19 Infection Undergoing Immunosuppression Therapy, a Case Report. Iranian journal of kidney diseases 2020, 14(3):239-242.

33. Farzi MA, Ayromlou H, Jahanbakhsh N, Bavil PH, Janzadeh A, Shayan FK: Guillain-Barré syndrome in a patient infected with SARS-CoV-2, a case report. Journal of Neuroimmunology 2020, 346.

34. Webb S, Wallace VC, Martin-Lopez D, Yogarajah M: Guillain-Barré syndrome following COVID-19: a newly emerging postinfectious complication. BMJ case reports 2020, 13(6).

35. Lantos JE, Strauss SB, Lin E: COVID-19-Associated Miller Fisher Syndrome: MRI Findings. AJNR American journal of neuroradiology 2020, 41(7):1184-1186.

36. Manganotti P, Pesavento V, Buoite Stella A, Bonzi L, Campagnolo E, Bellavita G, Fabris B, Luzzati R: Miller Fisher syndrome diagnosis and treatment in a patient with SARS-CoV-2. Journal of NeuroVirology 2020.

37. Virani A, Rabold E, Hanson T, Haag A, Elrufay R, Cheema T, Balaan M, Bhanot N: Guillain-Barré Syndrome associated with SARSCoV-2 infection. IDCases 2020, 20.

38. Rana S, Lima AA, Chandra R, Valeriano J, Desai T, Freiberg W, Small G: Novel Coronavirus (COVID-19)-Associated Guillain-Barré Syndrome: Case Report. Journal of clinical neuromuscular disease 2020, 21(4):240-242.

39. Artru F, Alberio L, Moradpour D, Stalder G: Acute immune thrombocytopaenic purpura in a patient with COVID-19 and decompensated cirrhosis. BMJ case reports 2020, 13(7).

40. Yang Y, Zhao J, Wu J, Teng Y, Xia X: A Rare Case of Immune Thrombocytopenic Purpura Secondary to CoVID-19. Journal of Medical Virology 2020.

41. Bomhof G, Mutsaers PGNJ, Leebeek FWG, te Boekhorst PAW, Hofland J, Croles FN, Jansen AJG: COVID-19-associated immune thrombocytopenia. British Journal of Haematology 2020.

42. Lévesque V, Millaire É, Corsilli D, Rioux-Massé B, Carrier FM: Severe immune thrombocytopenic purpura in critical COVID-19. International Journal of Hematology 2020.

43. Hayden A, Vyas-Lahar A, Rella V, Rudinskaya A: Severe refractory thrombocytopenia in a woman positive for coronavirus disease 2019 with lupus and antiphospholipid syndrome. Lupus 2020.

44. Quintana-Castanedo L, Feito-Rodríguez M, Fernández-Alcalde C, Granados-Fernández M, Montero-Vega D, Mayor-lbarguren A, de Lucas-Laguna R: Concurrent chilblains and retinal vasculitis in a child with COVID-19. Journal of the European Academy of Dermatology and Venereology : JEADV 2020.

45. Mayor-Ibarguren A, Feito-Rodriguez M, Quintana Castanedo L, Ruiz-Bravo E, Montero Vega D, Herranz-Pinto P: Cutaneous small vessel vasculitis secondary to COVID-19 infection: A case report. Journal of the European Academy of Dermatology and Venereology 2020.

46. Negrini S, Guadagno A, Greco M, Parodi A, Burlando M: An unusual case of bullous haemorrhagic vasculitis in a COVID-19 patient. Journal of the European Academy of Dermatology and Venereology 2020.

47. Del Giudice P, Boudoumi D, Le Guen B, Reverte M, Gutnecht J, Lacour JP, Kraemer JP, Motard A, Roa M: Catastrophic acute bilateral lower limbs necrosis associated with COVID-19 as a likely consequence of both vasculitis and coagulopathy. Journal of the European Academy of Dermatology and Venereology : JEADV 2020. 
48. Nasiri S, Araghi F, Tabary M, Gheisari M, Mahboubi-Fooladi Z, Dadkhahfar S: A challenging case of psoriasis flare-up after COVID-19 infection. Journal of Dermatological Treatment 2020, 31(5):448-449.

49. Novi G, Rossi T, Pedemonte E, Saitta L, Rolla C, Roccatagliata L, Inglese M, Farinini D: Acute disseminated encephalomyelitis after SARS-CoV-2 infection. Neurology(R) neuroimmunology \& neuroinflammation 2020, 7(5).

50. Pfefferkorn T, Dabitz R, von Wernitz-Keibel T, Aufenanger J, Nowak-Machen M, Janssen H: Acute polyradiculoneuritis with locked-in syndrome in a patient with Covid-19. Journal of Neurology 2020, 267(7):1883-1884.

51. Panariello A, Bassetti R, Radice A, Rossotti R, Puoti M, Corradin M, Moreno M, Percudani M: Anti-NMDA receptor encephalitis in a psychiatric Covid-19 patient: A case report. Brain, Behavior, and Immunity 2020:179-181.

52. Vega Hernández P, Borges Rivas Y, Ortega Sánchez E, Marqués Cabrero A, Remedios Mateo L, Silvera Roig P, Infante Quintanar A, Díaz-Delgado Peñas R, Sánchez Escudero V, García-García ML: Autoimmune Hemolytic Anemia in a Pediatric Patient With Severe Acute Respiratory Syndrome Coronavirus 2 Infection. The Pediatric infectious disease journal 2020.

53. Yokogawa N, Minematsu N, Katano H, Suzuki T: Case of acute arthritis following SARS-CoV-2 infection. Annals of the rheumatic diseases 2020.

54. Pinto AA, Carroll LS, Nar V, Varatharaj A, Galea I: CNS inflammatory vasculopathy with antimyelin oligodendrocyte glycoprotein antibodies in COVID-19. Neurology(R) neuroimmunology \& neuroinflammation 2020, 7(5).

55. Singh S, Govindarajan R: COVID-19 and generalized Myasthenia Gravis exacerbation: A case report. Clinical Neurology and Neurosurgery 2020, 196.

56. Capes A, Bailly S, Hantson P, Gerard L, Laterre PF: COVID-19 infection associated with autoimmune hemolytic anemia. Annals of Hematology 2020, 99(7):1679-1680.

57. Barzegar M, Mirmosayyeb O, Nehzat N, Sarrafi R, Khorvash F, Maghzi AH, Shaygannejad V: COVID-19 infection in a patient with multiple sclerosis treated with fingolimod. Neurology(R) neuroimmunology \& neuroinflammation 2020, 7(4).

58. Murt A, Eskazan AE, Yılmaz U, Ozkan T, Ar MC: COVID-19 presenting with immune thrombocytopenia: A case report and review of the literature. Journal of Medical Virology 2020.

59. Zhao H, Shen D, Zhou H, Liu J, Chen S: Guillain-Barré syndrome associated with SARS-CoV-2 infection: causality or coincidence? The Lancet Neurology 2020, 19(5):383-384.

60. Padroni M, Mastrangelo V, Asioli GM, Pavolucci L, Abu-Rumeileh S, Piscaglia MG, Querzani P, Callegarini C, Foschi M: GuillainBarré syndrome following COVID-19: new infection, old complication? Journal of Neurology 2020, 267(7):1877-1879.

61. Alberti P, Beretta S, Piatti M, Karantzoulis A, Piatti ML, Santoro P, Viganò M, Giovannelli G, Pirro F, Montisano DA et al: GuillainBarré syndrome related to COVID-19 infection. Neurology: Neuroimmunology and Neurolnflammation 2020, 7(4).

62. Zulfiqar AA, Lorenzo-Villalba N, Hassler P, Andrès E: Immune thrombocytopenic purpura in a patient with covid-19. New England Journal of Medicine 2020, 382(18):E43.

63. Nesr G, Garnett C, Bailey C, Arami S: ITP flare with mild COVID-19 infection in pregnancy: A case report. British Journal of Haematology 2020.

64. Arnaud S, Budowski C, Ng Wing Tin S, Degos B: Post SARS-CoV-2 Guillain-Barré syndrome. Clinical Neurophysiology 2020, 131(7):1652-1654.

65. Ma J, Xia P, Zhou Y, Liu Z, Zhou X, Wang J, Li T, Yan X, Chen L, Zhang S et al: Potential effect of blood purification therapy in reducing cytokine storm as a late complication of critically ill COVID-19. Clinical Immunology 2020, 214.

66. Hu Z, Chen W, Liang W, Xu C, Sun W, Yi Y: Severe exacerbation of immune thrombocytopenia and COVID-19: the favorable response to corticosteroid-based therapy-a case report. Annals of Hematology 2020.

67. Lopez C, Kim J, Pandey A, Huang T, DeLoughery TG: Simultaneous onset of COVID-19 and autoimmune haemolytic anaemia. British Journal of Haematology 2020, 190(1):31-32.

68. Abdi S, Ghorbani A, Fatehi F: The association of SARS-CoV-2 infection and acute disseminated encephalomyelitis without prominent clinical pulmonary symptoms. Journal of the Neurological Sciences 2020, 416.

69. Oriot P, Hermans MP: Euglycemic diabetic ketoacidosis in a patient with type 1 diabetes and SARS-CoV-2 pneumonia: case report and review of the literature. Acta Clinica Belgica: International Journal of Clinical and Laboratory Medicine 2020.

70. Reyes-Bueno JA, García-Trujillo L, Urbaneja P, Ciano-Petersen NL, Postigo-Pozo MJ, Martínez-Tomás C, Serrano-Castro PJ: MillerFisher syndrome after SARS-CoV-2 infection. European Journal of Neurology 2020. 
71. Waltuch T, Gill P, Zinns LE, Whitney R, Tokarski J, Tsung JW, Sanders JE: Features of COVID-19 post-infectious cytokine release syndrome in children presenting to the emergency department. American Journal of Emergency Medicine 2020.

72. Sokolovsky S, Soni P, Hoffman T, Kahn P, Scheers-Masters J: COVID-19 associated Kawasaki-like multisystem inflammatory disease in an adult. American Journal of Emergency Medicine 2020.

73. Albiol N, Awol R, Martino R: Autoimmune thrombotic thrombocytopenic purpura (TTP) associated with COVID-19. Annals of Hematology 2020, 99(7):1673-1674.

74. Chiotos K, Bassiri H, Behrens EM, Blatz AM, Chang J, Diorio C, Fitzgerald JC, Topjian A, John ARO: Multisystem Inflammatory Syndrome in Children During the Coronavirus 2019 Pandemic: A Case Series. Journal of the Pediatric Infectious Diseases Society 2020, 9(3):393-398.

75. Kutlu Ö, Metin A: A case of exacerbation of psoriasis after oseltamivir and hydroxychloroquine in a patient with COVID-19: Will cases of psoriasis increase after COVID-19 pandemic? Dermatologic Therapy 2020.

76. Beccuti G, Ghizzoni L, Cambria V, Codullo V, Sacchi P, Lovati E, Mongodi S, lotti GA, Mojoli F: A COVID-19 pneumonia case report of autoimmune polyendocrine syndrome type 1 in Lombardy, Italy: letter to the editor. Journal of Endocrinological Investigation 2020, 43(8):1175-1177.

77. Zhang Y, Xiao M, Zhang S, Xia P, Cao W, Jiang W, Chen H, Ding X, Zhao H, Zhang H et al: Coagulopathy and antiphospholipid antibodies in patients with covid-19. New England Journal of Medicine 2020, 382(17):E38.

78. Brun G, Hak JF, Coze S, Kaphan E, Carvelli J, Girard N, Stellmann JP: COVID-19-White matter and globus pallidum lesions: Demyelination or small-vessel vasculitis? Neurology(R) neuroimmunology \& neuroinflammation 2020, 7(4).

79. Bruni A, Garofalo E, Zuccalà V, Currò G, Torti C, Navarra G, De Sarro G, Navalesi P, Longhini F, Ammendola M: Histopathological findings in a COVID-19 patient affected by ischemic gangrenous cholecystitis. World journal of emergency surgery : WJES 2020, 15(1):43.

80. Reichard RR, Kashani KB, Boire NA, Constantopoulos E, Guo Y, Lucchinetti CF: Neuropathology of COVID-19: a spectrum of vascular and acute disseminated encephalomyelitis (ADEM)-like pathology. Acta Neuropathologica 2020, 140(1).

81. Verheyden M, Grosber M, Gutermuth J, Velkeniers B: Relapsing symmetric livedo reticularis in a patient with COVID-19 infection. Journal of the European Academy of Dermatology and Venereology : JEADV 2020.

82. Pilotto A, Odolini S, Stefano Masciocchi S, Comelli A, Volonghi I, Gazzina S, Nocivelli S, Pezzini A, Focà E, Caruso A et al: Steroidresponsive encephalitis in Covid-19 disease. Annals of Neurology 2020.

83. Wei H, Yin H, Huang M, Guo Z: The 2019 novel cornoavirus pneumonia with onset of oculomotor nerve palsy: a case study. Journal of Neurology 2020, 267(5):1550-1553.

84. Rosen MH, Axelrad J, Hudesman D, Rubin DT, Chang S: Management of Acute Severe Ulcerative Colitis in a Pregnant Woman With COVID-19 Infection: A Case Report and Review of the Literature. Inflammatory bowel diseases 2020, 26(7):971-973.

85. Cerasti D, Ormitti F, Pardatscher S, Malchiodi L, Picetti E, Menozzi R, Rossi S: Multiple Acute Ischemic Strokes in a COVID-19 Patient: a Case Report. SN Comprehensive Clinical Medicine 2020.

86. Lee JM, Lee SJ: Olfactory and Gustatory Dysfunction in a COVID-19 Patient with Ankylosing Spondylitis Treated with Etanercept: Case Report. Journal of Korean medical science 2020, 35(21):e201.

87. Arca KN, Starling AJ: Treatment-Refractory Headache in the Setting of COVID-19 Pneumonia: Migraine or Meningoencephalitis? Case Report. SN Comprehensive Clinical Medicine 2020.

88. Zoghi A, Ramezani M, Roozbeh M, Darazam IA, Sahraian MA: A case of possible atypical demyelinating event of the central nervous system following COVID-19. Multiple Sclerosis and Related Disorders 2020, 44.

89. Anand P, Slama MCC, Kaku M, Ong C, Cervantes-Arslanian AM, Zhou L, David WS, Guidon AC: COVID-19 in patients with myasthenia gravis. Muscle and Nerve 2020, 62(2):254-258.

90. Dogan L, Kaya D, Sarikaya T, Zengin R, Dincer A, Ozkan Akinci I, Afsar N: Plasmapheresis treatment in CoVID-19-related autoimmune meningoencephalitis: Case series. Brain, behavior, and immunity 2020.

91. Wu C, Chen X, Cai Y, Xia Ja, Zhou X, Xu S, Huang H, Zhang L, Zhou X, Du C et al: Risk Factors Associated With Acute Respiratory Distress Syndrome and Death in Patients With Coronavirus Disease 2019 Pneumonia in Wuhan, China. JAMA Internal Medicine 2020, 180(7):934-943. 
92. Zhou F, Yu T, Du R, Fan G, Liu Y, Liu Z, Xiang J, Wang Y, Song B, Gu X et al: Clinical course and risk factors for mortality of adult inpatients with COVID-19 in Wuhan, China: a retrospective cohort study. The Lancet 2020, 395(10229):1054-1062.

93. Ngo ST, Steyn FJ, McCombe PA: Gender differences in autoimmune disease. Frontiers in Neuroendocrinology 2014, 35(3):347369.

94. Rodriguez-Morales AJ, Cardona-Ospina JA, Gutiérrez-Ocampo E, Villamizar-Peña R, Holguin-Rivera Y, Escalera-Antezana JP, Alvarado-Arnez LE, Bonilla-Aldana DK, Franco-Paredes C, Henao-Martinez AF et al: Clinical, laboratory and imaging features of COVID-19: A systematic review and meta-analysis. Travel Medicine and Infectious Disease 2020, 34:101623.

95. Correia AO, Feitosa PWG, de Sousa Moreira JL, Nogueira SÁR, Fonseca RB, Nobre MEPJN, Psychiatry, Research B: Neurological manifestations of COVID-19 and other coronaviruses: a systematic review. 2020.

96. Helms J, Kremer S, Merdji H, Clere-Jehl R, Schenck M, Kummerlen C, Collange O, Boulay C, Fafi-Kremer S, Ohana MJNEJoM: Neurologic features in severe SARS-CoV-2 infection. 2020.

97. Mao L, Jin H, Wang M, Hu Y, Chen S, He Q, Chang J, Hong C, Zhou Y, Wang DJJn: Neurologic manifestations of hospitalized patients with coronavirus disease 2019 in Wuhan, China. 2020, 77(6):683-690.

98. Romero-Sánchez CM, Díaz-Maroto I, Fernández-Díaz E, Sánchez-Larsen Á, Layos-Romero A, García-García J, González E, Redondo-Peñas I, Perona-Moratalla AB, Del Valle-Pérez JAJN: Neurologic manifestations in hospitalized patients with COVID-19: The ALBACOVID registry. 2020.

99. Netland J, Meyerholz DK, Moore S, Cassell M, Perlman SJJov: Severe acute respiratory syndrome coronavirus infection causes neuronal death in the absence of encephalitis in mice transgenic for human ACE2. 2008, 82(15):7264-7275.

100. Baig AM, Khaleeq A, Ali U, Syeda HJAcn: Evidence of the COVID-19 virus targeting the CNS: tissue distribution, host-virus interaction, and proposed neurotropic mechanisms. 2020, 11(7):995-998.

101. Hughes RA, Cornblath DRJTL: Guillain-barre syndrome. 2005, 366(9497):1653-1666.

102. Yuki N, Hartung H-PJNEJoM: Guillain-Barré syndrome. 2012, 366(24):2294-2304.

103. Tenembaum S, Chitnis T, Ness J, Hahn JSJN: Acute disseminated encephalomyelitis. 2007, 68(16 suppl 2):S23-S36.

104. Rowley AHJArom: Kawasaki disease: novel insights into etiology and genetic susceptibility. 2011, 62:69-77.

105. Nardi M, Tomlinson S, Greco MA, Karpatkin SJC: Complement-independent, peroxide-induced antibody lysis of platelets in HIV-1related immune thrombocytopenia. 2001, 106(5):551-561.

106. Rodeghiero F, Stasi R, Gernsheimer T, Michel M, Provan D, Arnold DM, Bussel JB, Cines DB, Chong BH, Cooper NJB: Standardization of terminology, definitions and outcome criteria in immune thrombocytopenic purpura of adults and children: report from an international working group. 2009, 113(11):2386-2393.

107. Scaradavou AJBr: HIV-related thrombocytopenia. 2002, 16(1):73-76.

108. McMillan RJJopho: Antiplatelet antibodies in chronic adult immune thrombocytopenic purpura: assays and epitopes. 2003, 25:S57-S61.

109. Lippi G, Plebani M, Henry BMJCCA: Thrombocytopenia is associated with severe coronavirus disease 2019 (COVID-19) infections: a meta-analysis. 2020.

110. Levine JS, Branch DW, Rauch JJNEJoM: The antiphospholipid syndrome. 2002, 346(10):752-763.

111. Abdel-Wahab N, Lopez-Olivo MA, Pinto-Patarroyo GP, Suarez-Almazor ME: Systematic review of case reports of antiphospholipid syndrome following infection. 2016, 25(14):1520-1531.

112. Cervera R, Asherson RA, Acevedo ML, Gómez-Puerta JA, Espinosa G, de la Red G, Gil V, Ramos-Casals M, García-Carrasco M, Ingelmo $\mathrm{M}$ et al: Antiphospholipid syndrome associated with infections: clinical and microbiological characteristics of 100 patients. 2004, 63(10):1312-1317.

\section{Tables}

Table 1. Summary of general population and case characteristics. 


\begin{tabular}{|c|c|c|c|c|c|c|}
\hline Study & $\begin{array}{c}\text { Patient's } \\
\text { characteristics }\end{array}$ & $\begin{array}{c}\text { COVID-19 } \\
\text { confirmation } \\
\text { test } \\
\text { COVID-19 } \\
\text { to AD } \\
\text { latency }\end{array}$ & $\begin{array}{l}\text { AD developed } \\
\text { vs } \\
\text { AD exacerbation }\end{array}$ & $\begin{array}{l}\text { Main AD related } \\
\text { laboratory findings }\end{array}$ & Treatment & $\begin{array}{l}\text { Admission and } \\
\text { outcomes }\end{array}$ \\
\hline $\begin{array}{l}\text { Sedaghat, Z. and N. } \\
\text { Karimi [22] (2020) } \\
\text { Iran } \\
\text { Case report }\end{array}$ & $\begin{array}{l}\text { Male } \\
65 \\
\text { DM (Type 2) }\end{array}$ & $\begin{array}{l}\text { COVID-19 } \\
\text { confirmation } \\
\text { test: } \\
\text { Positive rRT- } \\
\text { PCR } \\
\text { COVID-19 } \\
\text { to AD } \\
\text { latency: } \\
<14 \text { days }\end{array}$ & $\begin{array}{l}\text { De novo: Guillain- } \\
\text { Barré syndrome } \\
\text { (Acute motor and } \\
\text { sensory axonal } \\
\text { neuropathy) }\end{array}$ & - & $\begin{array}{l}\text { AD: Immunoglobulin } \\
\text { COVID-19: Hydroxychloroquine; } \\
\text { Lopinavir/Ritonavir; } \\
\text { Azithromycin }\end{array}$ & $\begin{array}{l}\text { Hospitalization: } \\
>14 \text { days } \\
\text { Outcome: Not } \\
\text { reported }\end{array}$ \\
\hline $\begin{array}{l}\text { Chiu, J. S., et } \\
\text { al. [23] (2020) } \\
\text { USA } \\
\text { Case report }\end{array}$ & $\begin{array}{l}\text { Male } \\
10\end{array}$ & $\begin{array}{l}\text { COVID-19 } \\
\text { confirmation } \\
\text { test: } \\
\text { Positive rRT- } \\
\text { PCR } \\
\text { COVID-19 } \\
\text { to AD } \\
\text { latency: } \\
0 \text { days }\end{array}$ & $\begin{array}{l}\text { De novo: Kawasaki } \\
\text { Disease }\end{array}$ & - & $\begin{array}{l}\text { AD: Ibuprofen; Normal saline } \\
\text { bolus; Dopamine }\end{array}$ & $\begin{array}{l}\text { Hospitalization: } \\
\text { unknown } \\
\text { duration } \\
\text { Outcome: Not } \\
\text { reported }\end{array}$ \\
\hline $\begin{array}{l}\text { Allez, M., et } \\
\text { al. [24] (2020) } \\
\text { France } \\
\text { Case report }\end{array}$ & $\begin{array}{l}\text { Male } \\
24\end{array}$ & $\begin{array}{l}\text { COVID-19 } \\
\text { confirmation } \\
\text { test: } \\
\text { Positive rRT- } \\
\text { PCR } \\
\text { COVID-19 } \\
\text { to AD } \\
\text { latency: } \\
\text { Unclear }\end{array}$ & $\begin{array}{l}\text { De novo: IgA } \\
\text { vasculitis } \\
\text { Exacerbation: } \\
\text { Crohn's disease } \\
\text { (Previously in } \\
\text { remission with: } \\
\text { Ileocecal surgical } \\
\text { resection; } \\
\text { Adalimumab) }\end{array}$ & - & $\begin{array}{l}\text { AD: Low molecular weight } \\
\text { heparin; Methylprednisolone }\end{array}$ & $\begin{array}{l}\text { Hospitalization: } \\
7 \text { days } \\
\text { Outcome: } \\
\text { Favorable }\end{array}$ \\
\hline $\begin{array}{l}\text { Dolinger, M. T., et } \\
\text { al. [25] (2020) } \\
\text { USA } \\
\text { Case report }\end{array}$ & $\begin{array}{c}\text { Male } \\
14\end{array}$ & $\begin{array}{l}\text { COVID-19 } \\
\text { confirmation } \\
\text { test: } \\
\text { Positive rRT- } \\
\text { PCR } \\
\text { COVID-19 } \\
\text { to AD } \\
\text { latency: } \\
0 \text { days }\end{array}$ & $\begin{array}{l}\text { De novo: MIS-C } \\
\text { Exacerbation: } \\
\text { Crohn's disease } \\
\text { (Previously active) }\end{array}$ & $\begin{array}{l}\text { High serum IL-6; } \\
\text { High serum IL-8; } \\
\text { High serum TNF- } \alpha\end{array}$ & $\begin{array}{l}\text { AD: Enoxaparin; Intravenous } \\
\text { fluid therapy; Infliximab; } \\
\text { Piperacillin/tazobactam; } \\
\text { Drainage of perianal abscess; } \\
\text { Ciprofloxacin; Metronidazole } \\
\text { COVID-19: Hydroxychloroquine; } \\
\text { Azithromycin }\end{array}$ & $\begin{array}{l}\text { Hospitalization: } \\
13 \text { days } \\
\text { Outcome: } \\
\text { Favorable }\end{array}$ \\
\hline $\begin{array}{l}\text { Ottaviani, D., et } \\
\text { al. [26] (2020) } \\
\text { Italy } \\
\text { Case report }\end{array}$ & $\begin{array}{l}\text { Female } \\
66 \\
\text { Hypertension }\end{array}$ & $\begin{array}{l}\text { COVID-19 } \\
\text { confirmation } \\
\text { test: } \\
\text { Positive rRT- } \\
\text { PCR } \\
\text { COVID-19 } \\
\text { to AD } \\
\text { latency: } \\
7 \text { days }\end{array}$ & $\begin{array}{l}\text { De novo: Guillain- } \\
\text { Barré syndrome }\end{array}$ & - & $\begin{array}{l}\text { AD: Immunoglobulin } \\
\text { COVID-19: Lopinavir/Ritonavir; } \\
\text { Hydroxychloroquine; Intubation }\end{array}$ & $\begin{array}{l}\text { Hospitalization: } \\
>10 \text { days } \\
\text { ICU admission: } \\
\text { Yes } \\
\text { Outcome: Not } \\
\text { reported }\end{array}$ \\
\hline $\begin{array}{l}\text { Scheidl, E., et } \\
\text { al. [27] (2020). } \\
\text { Germany } \\
\text { Case report }\end{array}$ & $\begin{array}{l}\text { Female } \\
54\end{array}$ & $\begin{array}{l}\text { COVID-19 } \\
\text { confirmation } \\
\text { test: } \\
\text { Positive rRT- } \\
\text { PCR } \\
\text { COVID-19 } \\
\text { to AD } \\
\text { latency: } \\
21 \text { days }\end{array}$ & $\begin{array}{l}\text { De novo: Guillain- } \\
\text { Barré syndrome } \\
\text { (Acute inflammatory } \\
\text { demyelinating } \\
\text { polyneuropathy) }\end{array}$ & $\begin{array}{l}\text { CSF high protein } \\
\text { level }\end{array}$ & AD: Immunoglobulin & $\begin{array}{l}\text { Hospitalization: } \\
>7 \text { days } \\
\text { Outcome: } \\
\text { Favorable }\end{array}$ \\
\hline $\begin{array}{l}\text { Parsons, T., et } \\
\text { al. [28] (2020) }\end{array}$ & $\begin{array}{l}\text { Female } \\
51\end{array}$ & $\begin{array}{l}\text { COVID-19 } \\
\text { confirmation }\end{array}$ & $\begin{array}{l}\text { De novo: Acute } \\
\text { disseminated }\end{array}$ & $\begin{array}{l}\text { CSF high protein } \\
\text { level }\end{array}$ & $\begin{array}{l}\text { AD: Methylprednisolone; } \\
\text { Immunoglobulin }\end{array}$ & $\begin{array}{l}\text { Hospitalization: } \\
\geq 59 \text { days }\end{array}$ \\
\hline
\end{tabular}


PCR

COVID-19

to $\mathrm{AD}$

latency:

[0-18] days

\begin{tabular}{|c|c|c|c|c|c|c|}
\hline $\begin{array}{l}\text { Zanin, L., et } \\
\text { al. [29] (2020). } \\
\text { Italy } \\
\text { Case report }\end{array}$ & $\begin{array}{l}\text { Female } \\
54 \\
\text { Anterior } \\
\text { communicating } \\
\text { artery aneurysm }\end{array}$ & $\begin{array}{l}\text { COVID-19 } \\
\text { confirmation } \\
\text { test: } \\
\text { Positive rRT- } \\
\text { PCR } \\
\text { COVID-19 } \\
\text { to AD } \\
\text { latency: } \\
>1 \text { day }\end{array}$ & $\begin{array}{l}\text { De novo: Acute } \\
\text { disseminated } \\
\text { encephalomyelitis }\end{array}$ & & $\begin{array}{l}\text { AD: Acosamide; Levetiracetam; } \\
\text { Phenytoin } \\
\text { COVID-19: Antiretroviral; } \\
\text { Hydroxychloroquine; } \\
\text { Dexamethasone; Intubation; } \\
\text { Tracheostomy }\end{array}$ & $\begin{array}{l}\text { Hospitalization: } \\
\geq 34 \text { days } \\
\text { ICU admission: } \\
\text { Yes } \\
\text { Outcome: } \\
\text { Favorable }\end{array}$ \\
\hline $\begin{array}{l}\text { Hanafi, R, et } \\
\text { al. [30] (2020) } \\
\text { France } \\
\text { Case report }\end{array}$ & $\begin{array}{l}\text { Male } \\
65\end{array}$ & $\begin{array}{l}\text { COVID-19 } \\
\text { confirmation } \\
\text { test: } \\
\text { Positive rRT- } \\
\text { PCR } \\
\text { COVID-19 } \\
\text { to AD } \\
\text { latency: } \\
6 \text { days }\end{array}$ & $\begin{array}{l}\text { De novo: CNS } \\
\text { Vasculitis }\end{array}$ & Thrombocytopenia & $\begin{array}{l}\text { COVID-19: Oxygen therapy } \\
\text { (high-concentration mask } \\
(15 \mathrm{~L} / \mathrm{min}) \text { ); Spiramycin; } \\
\text { Amoxicillin and clavulanic acid }\end{array}$ & $\begin{array}{l}\text { Hospitalization: } \\
>6 \text { days } \\
\text { ICU admission: } \\
\text { Yes } \\
\text { Outcome: Not } \\
\text { reported }\end{array}$ \\
\hline
\end{tabular}

\begin{tabular}{|c|c|c|c|c|c|c|}
\hline $\begin{array}{l}\text { Patil, N. R., et } \\
\text { al. [31] (2020) } \\
\text { USA } \\
\text { Case report }\end{array}$ & $\begin{array}{l}\text { Female } \\
51 \\
\text { Breast cancer; } \\
\text { Venous } \\
\text { thromboembolism }\end{array}$ & $\begin{array}{l}\text { COVID-19 } \\
\text { confirmation } \\
\text { test: } \\
\text { Positive rRT- } \\
\text { PCR } \\
\text { COVID-19 } \\
\text { to AD } \\
\text { latency: } \\
\text { Unclear }\end{array}$ & $\begin{array}{l}\text { De novo: } \\
\text { Autoimmune } \\
\text { hemolytic anemia } \\
\text { (Cold agglutinin } \\
\text { disease) }\end{array}$ & Anemia & $\begin{array}{l}\text { AD: Red blood cell transfusion; } \\
\text { Folic acid; Recommended use of } \\
\text { warm intravenous fluids and } \\
\text { blood products; Unfractionated } \\
\text { heparin } \\
\text { COVID-19: Hydroxychloroquine; } \\
\text { Oxygen therapy ( } 6 \mathrm{~L} / \mathrm{min}) \text {; } \\
\text { Methylprednisolone }\end{array}$ & $\begin{array}{l}\text { Hospitalization: } \\
>4 \text { days } \\
\text { Outcome: } \\
\text { Favorable }\end{array}$ \\
\hline $\begin{array}{l}\text { Moeinzadeh, F., et } \\
\text { al. [32] (2020). } \\
\text { Iran } \\
\text { Case report }\end{array}$ & $\begin{array}{l}\text { Male } \\
25\end{array}$ & $\begin{array}{l}\text { COVID-19 } \\
\text { confirmation } \\
\text { test: } \\
\text { Positive rRT- } \\
\text { PCR } \\
\text { COVID-19 } \\
\text { to AD } \\
\text { latency: } \\
0 \text { days }\end{array}$ & $\begin{array}{l}\text { Exacerbation: ANCA- } \\
\text { associated vasculitis } \\
\text { - Glomerulonephritis } \\
\text { (Previously active } \\
\text { with: } \\
\text { Hydroxychloroquine) }\end{array}$ & $\begin{array}{l}\text { Anemia; Positive } \\
\text { C-ANCA }\end{array}$ & $\begin{array}{l}\text { AD: Methylprednisolone; } \\
\text { Plasmapheresis; } \\
\text { Immunoglobulin; } \\
\text { Cyclophosphamide } \\
\text { COVID-19: Hydroxychloroquine; } \\
\text { Levofloxacin }\end{array}$ & $\begin{array}{l}\text { Hospitalization: } \\
15 \text { days } \\
\text { Outcome: } \\
\text { Favorable }\end{array}$ \\
\hline $\begin{array}{l}\text { Farzi, M. A., et } \\
\text { al. [33] (2020). } \\
\text { Iran } \\
\text { Case report }\end{array}$ & $\begin{array}{l}\text { Male } \\
41 \\
\text { DM (Type 2) }\end{array}$ & $\begin{array}{l}\text { COVID-19 } \\
\text { confirmation } \\
\text { test: } \\
\text { Positive rRT- } \\
\text { PCR } \\
\text { COVID-19 } \\
\text { to AD } \\
\text { latency: } \\
10 \text { days }\end{array}$ & $\begin{array}{l}\text { De novo: Guillain- } \\
\text { Barré syndrome } \\
\text { (Acute inflammatory } \\
\text { demyelinating } \\
\text { polyneuropathy) }\end{array}$ & - & $\begin{array}{l}\text { AD: Immunoglobulin } \\
\text { COVID-19: Lopinavir/Ritonavir; } \\
\text { Hydroxychloroquine }\end{array}$ & $\begin{array}{l}\text { Hospitalization: } \\
>17 \text { days } \\
\text { Outcome: } \\
\text { Favorable }\end{array}$ \\
\hline $\begin{array}{l}\text { Webb, S., et } \\
\text { al. [34] (2020) } \\
\text { UK } \\
\text { Case report }\end{array}$ & $\begin{array}{l}\text { Male } \\
57 \\
\text { Hypertension }\end{array}$ & $\begin{array}{l}\text { COVID-19 } \\
\text { confirmation } \\
\text { test: } \\
\text { Positive rRT- } \\
\text { PCR } \\
\text { COVID-19 } \\
\text { to AD } \\
\text { latency: } \\
7 \text { days }\end{array}$ & $\begin{array}{l}\text { De novo: Guillain- } \\
\text { Barré syndrome } \\
\text { (Acute inflammatory } \\
\text { demyelinating } \\
\text { polyneuropathy) } \\
\text { Exacerbation: } \\
\text { Psoriasis } \\
\text { (Status not } \\
\text { specified) }\end{array}$ & $\begin{array}{l}\text { CSF high protein } \\
\text { level }\end{array}$ & $\begin{array}{l}\text { AD: Immunoglobulin; Intubation; } \\
\text { Tracheostomy } \\
\text { COVID-19: Amoxicillin and } \\
\text { clavulanic acid }\end{array}$ & $\begin{array}{l}\text { Hospitalization: } \\
>7 \text { days } \\
\text { ICU admission: } \\
\text { Yes } \\
\text { Outcome: Not } \\
\text { reported }\end{array}$ \\
\hline
\end{tabular}




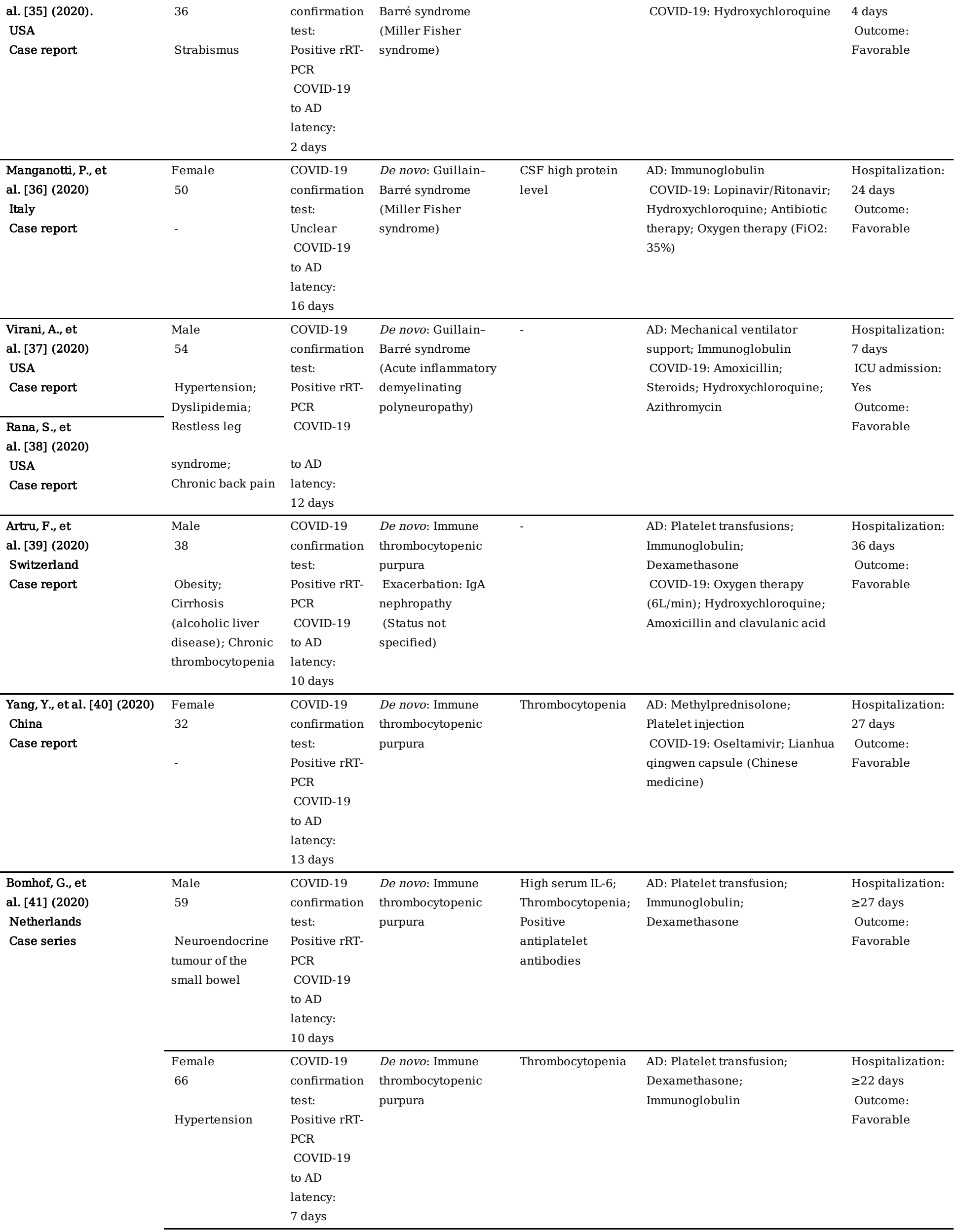




\begin{tabular}{|c|c|c|c|c|c|c|}
\hline & $\begin{array}{l}\text { Male } \\
67 \\
\text { Hypertension; } \\
\text { DM }\end{array}$ & $\begin{array}{l}\text { COVID-19 } \\
\text { confirmation } \\
\text { test: } \\
\text { Positive rRT- } \\
\text { PCR } \\
\text { COVID-19 } \\
\text { to AD } \\
\text { latency: } \\
17 \text { days }\end{array}$ & $\begin{array}{l}\text { De novo: Immune } \\
\text { thrombocytopenic } \\
\text { purpura }\end{array}$ & $\begin{array}{l}\text { High serum IL-6; } \\
\text { Thrombocytopenia }\end{array}$ & $\begin{array}{l}\text { AD: Platelet transfusions } \\
\text { COVID-19: Intubation; } \\
\text { Unfractionated heparin }\end{array}$ & $\begin{array}{l}\text { Hospitalization: } \\
13 \text { days } \\
\text { ICU admission: } \\
\text { Yes } \\
\text { Outcome: } \\
\text { Death }\end{array}$ \\
\hline $\begin{array}{l}\text { Lévesque, V., et } \\
\text { al. [42] (2020) } \\
\text { Canada } \\
\text { Case report }\end{array}$ & $\begin{array}{l}\text { Male } \\
53 \\
\text { Hypertension; } \\
\text { Dyslipidemia; DM } \\
\text { (Type 2) }\end{array}$ & $\begin{array}{l}\text { COVID-19 } \\
\text { confirmation } \\
\text { test: } \\
\text { Positive rRT- } \\
\text { PCR } \\
\text { COVID-19 } \\
\text { to AD } \\
\text { latency: } \\
23 \text { days }\end{array}$ & $\begin{array}{l}\text { De novo: Immune } \\
\text { thrombocytopenic } \\
\text { purpura }\end{array}$ & $\begin{array}{l}\text { Thrombocytopenia; } \\
\text { Positive anti-PF4 }\end{array}$ & $\begin{array}{l}\text { AD: Immunoglobulin; } \\
\text { Dexamethasone; Platelet } \\
\text { transfusions; Red blood cell } \\
\text { transfusions; Tranexamic acid; } \\
\text { Endobronchial clot removal; } \\
\text { Romiplostim; Vincristine; } \\
\text { Methylprednisolone (pulse } \\
\text { doses) } \\
\text { COVID-19: Intubation; } \\
\text { Mechanical ventilator support; } \\
\text { Prone positioning; Propofol; } \\
\text { Fentanyl; Cisatracurium; } \\
\text { Ceftriaxone; Azithromycin; } \\
\text { Unfractionated heparin; } \\
\text { Tracheostomy }\end{array}$ & $\begin{array}{l}\text { Hospitalization: } \\
\geq 39 \text { days } \\
\text { ICU admission: } \\
\text { Yes } \\
\text { Outcome: } \\
\text { Favorable }\end{array}$ \\
\hline $\begin{array}{l}\text { Hayden, A., et } \\
\text { al. [43] (2020) } \\
\text { USA } \\
\text { Case report }\end{array}$ & $\begin{array}{l}\text { Female } \\
51 \\
-\end{array}$ & $\begin{array}{l}\text { COVID-19 } \\
\text { confirmation } \\
\text { test: } \\
\text { Positive rRT- } \\
\text { PCR } \\
\text { COVID-19 } \\
\text { to AD } \\
\text { latency: } \\
\text { Unclear }\end{array}$ & $\begin{array}{l}\text { Exacerbation: } \\
\text { Systemic lupus } \\
\text { erythematosus, } \\
\text { Antiphospholipid } \\
\text { syndrome } \\
\text { (Previously in } \\
\text { remission with: } \\
\text { Hydroxychloroquine; } \\
\text { Azathioprine; } \\
\text { Belimumab; } \\
\text { Warfarin) }\end{array}$ & 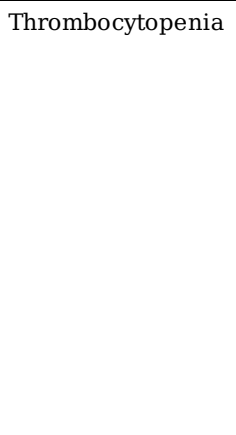 & $\begin{array}{l}\text { AD: Platelet transfusions; } \\
\text { Immunoglobulin; Prednisone; } \\
\text { Eltrombopag }\end{array}$ & $\begin{array}{l}\text { Hospitalization: } \\
12 \text { days } \\
\text { Outcome: } \\
\text { Favorable }\end{array}$ \\
\hline $\begin{array}{l}\text { Quintana-Castanedo, L., } \\
\text { et al [44]. (2020) } \\
\text { Spain } \\
\text { Case report }\end{array}$ & $\begin{array}{c}\text { Male } \\
11\end{array}$ & $\begin{array}{l}\text { COVID-19 } \\
\text { confirmation } \\
\text { test: } \\
\text { Negative } \\
\text { rRT-PCR; } \\
\text { Positive IgG } \\
\text { COVID-19 } \\
\text { to AD } \\
\text { latency: } \\
\text { Unclear }\end{array}$ & $\begin{array}{l}\text { De novo: Retinal } \\
\text { vasculitis }\end{array}$ & - & - & $\begin{array}{l}\text { Outcome: Not } \\
\text { reported }\end{array}$ \\
\hline $\begin{array}{l}\text { Mayor-Ibarguren, A., et } \\
\text { al [45]. (2020) } \\
\text { Spain } \\
\text { Case report }\end{array}$ & $\begin{array}{l}\text { Female } \\
83 \\
\text { Hypertension; } \\
\text { Transient } \\
\text { ischaemic attack; } \\
\text { Atrial fibrillation; } \\
\text { Chronic kidney } \\
\text { disease }\end{array}$ & $\begin{array}{l}\text { COVID-19 } \\
\text { confirmation } \\
\text { test: } \\
\text { Negative } \\
\text { rRT-PCR; } \\
\text { Positive IgM } \\
\text { and IgG } \\
\text { COVID-19 } \\
\text { to AD } \\
\text { latency: } \\
30 \text { days }\end{array}$ & $\begin{array}{l}\text { De novo: Cutaneous } \\
\text { small vessel } \\
\text { vasculitis }\end{array}$ & $\begin{array}{l}\text { Positive anti- } \\
\text { cardiolipin } \\
\text { antibodies }\end{array}$ & AD: Prednisone & $\begin{array}{l}\text { Hospitalization: } \\
10 \text { days } \\
\text { Outcome: } \\
\text { Favorable }\end{array}$ \\
\hline $\begin{array}{l}\text { Negrini, S., et } \\
\text { al. [46] }(2020) \\
\text { Italy } \\
\text { Case report }\end{array}$ & $\begin{array}{l}\text { Male } \\
79 \\
\text { Hypertension; } \\
\text { Myocardial } \\
\text { infarction; COPD; }\end{array}$ & $\begin{array}{l}\text { COVID-19 } \\
\text { confirmation } \\
\text { test: } \\
\text { Positive rRT- } \\
\text { PCR } \\
\text { COVID-19 }\end{array}$ & $\begin{array}{l}\text { De novo: Cutaneous } \\
\text { small vessel } \\
\text { vasculitis }\end{array}$ & - & $\begin{array}{l}\text { COVID-19: Hydroxychloroquine; } \\
\text { Enoxaparin; ceftaroline; } \\
\text { Methylprednisolone; Oxygen } \\
\text { therapy (8 L/min; FiO2: 40\%) }\end{array}$ & $\begin{array}{l}\text { Hospitalization: } \\
\text { >25 days } \\
\text { ICU admission: } \\
\text { Yes } \\
\text { Outcome: } \\
\text { Death }\end{array}$ \\
\hline
\end{tabular}


Acute heart to AD

failure latency:

10 days

\begin{tabular}{|c|c|c|c|c|c|c|}
\hline $\begin{array}{l}\text { Del Giudice, P., et } \\
\text { al. [47] (2020) } \\
\text { France } \\
\text { Case report }\end{array}$ & $\begin{array}{l}\text { Male } \\
83 \\
\text { Obesity; DM } \\
\text { (Type 2); } \\
\text { Hypertension; } \\
\text { Mesenteric } \\
\text { ischemia; Distal } \\
\text { arteriopathy; } \\
\text { Myocardial } \\
\text { infarction }\end{array}$ & $\begin{array}{l}\text { COVID-19 } \\
\text { confirmation } \\
\text { test: } \\
\text { Positive rRT- } \\
\text { PCR } \\
\text { COVID-19 } \\
\text { to AD } \\
\text { latency: } \\
13 \text { days }\end{array}$ & $\begin{array}{l}\text { De novo: Vasculitis } \\
\text { Exacerbation: } \\
\text { Polymyalgia } \\
\text { rheumatica } \\
\text { (Status not } \\
\text { specified; treated } \\
\text { with: Prednisolone) }\end{array}$ & Thrombocytopenia & - & $\begin{array}{l}\text { Hospitalization: } \\
>1 \text { days } \\
\text { Outcome: } \\
\text { Death }\end{array}$ \\
\hline $\begin{array}{l}\text { Nasiri, S., et } \\
\text { al. [48] (2020) } \\
\text { Iran } \\
\text { Case report }\end{array}$ & $\begin{array}{l}\text { Male } \\
73\end{array}$ & $\begin{array}{l}\text { COVID-19 } \\
\text { confirmation } \\
\text { test: } \\
\text { Positive rRT- } \\
\text { PCR } \\
\text { COVID-19 } \\
\text { to AD } \\
\text { latency: } \\
14 \text { days }\end{array}$ & $\begin{array}{l}\text { Exacerbation: } \\
\text { Psoriasis } \\
\text { (Status not } \\
\text { specified; treated } \\
\text { with: Cyclosporine; } \\
\text { Methotrexate) }\end{array}$ & - & $\begin{array}{l}\text { COVID-19: Hydroxychloroquine; } \\
\text { Lopinavir/Ritonavir; } \\
\text { Acetaminophen }\end{array}$ & $\begin{array}{l}\text { Hospitalization: } \\
7 \text { days } \\
\text { Outcome: } \\
\text { Favorable }\end{array}$ \\
\hline $\begin{array}{l}\text { Novi, G., et al. [49] (2020) } \\
\text { Italy } \\
\text { Case report }\end{array}$ & $\begin{array}{l}\text { Female } \\
64 \\
\text { Hypertension; } \\
\text { MGUS }\end{array}$ & $\begin{array}{l}\text { COVID-19 } \\
\text { confirmation } \\
\text { test: } \\
\text { Negative } \\
\text { rRT-PCR; } \\
\text { Positive IgG } \\
\text { COVID-19 } \\
\text { to AD } \\
\text { latency: } \\
25 \text { days }\end{array}$ & $\begin{array}{l}\text { De novo: Acute } \\
\text { disseminated } \\
\text { encephalomyelitis } \\
\text { Exacerbation: } \\
\text { Vitiligo } \\
\text { (Status not } \\
\text { specified) }\end{array}$ & $\begin{array}{l}\text { CSF high protein } \\
\text { level }\end{array}$ & $\begin{array}{l}\text { AD: Methylprednisolone; } \\
\text { Immunoglobulin; Prednisone }\end{array}$ & $\begin{array}{l}\text { Hospitalization: } \\
17 \text { days } \\
\text { Outcome: } \\
\text { Favorable }\end{array}$ \\
\hline $\begin{array}{l}\text { Pfefferkorn, T., et } \\
\text { al. [50] (2020). } \\
\text { Germany } \\
\text { Case report }\end{array}$ & $\begin{array}{c}\text { Male } \\
51\end{array}$ & $\begin{array}{l}\text { COVID-19 } \\
\text { confirmation } \\
\text { test: } \\
\text { Positive rRT- } \\
\text { PCR } \\
\text { COVID-19 } \\
\text { to AD } \\
\text { latency: } \\
12 \text { days }\end{array}$ & $\begin{array}{l}\text { De novo: Guillain- } \\
\text { Barré syndrome }\end{array}$ & $\begin{array}{l}\text { CSF high protein } \\
\text { level; Pleocytosis }\end{array}$ & $\begin{array}{l}\text { AD: Immunoglobulin; Plasma } \\
\text { exchange } \\
\text { COVID-19: Intubation; } \\
\text { Mechanical ventilator support; } \\
\text { Tracheostomy }\end{array}$ & $\begin{array}{l}\text { Hospitalization: } \\
31 \text { days } \\
\text { Outcome: } \\
\text { Favorable }\end{array}$ \\
\hline $\begin{array}{l}\text { Panariello, A., et } \\
\text { al. [51] (2020). } \\
\text { Italy } \\
\text { Case report }\end{array}$ & $\begin{array}{l}\text { Male } \\
23 \\
\text { Substance Use } \\
\text { Disorder (THC; } \\
\text { cocaine and } \\
\text { phencyclidine) }\end{array}$ & $\begin{array}{l}\text { COVID-19 } \\
\text { confirmation } \\
\text { test: } \\
\text { Positive rRT- } \\
\text { PCR } \\
\text { COVID-19 } \\
\text { to AD } \\
\text { latency: } \\
\text { Unclear }\end{array}$ & $\begin{array}{l}\text { De novo: Anti-NMDA } \\
\text { receptor encephalitis }\end{array}$ & $\begin{array}{l}\text { CSF high protein } \\
\text { level; Pleocytosis; } \\
\text { High serum IL-6; } \\
\text { Positive anti- } \\
\text { cardiolipin } \\
\text { antibodies }\end{array}$ & $\begin{array}{l}\text { AD: Haloperidol; Promazine; } \\
\text { Midazolam; Aripiprazole; } \\
\text { Quetiapine; Antibiotic } \\
\text { prophylactic therapy; Valproate; } \\
\text { Dexamethasone; } \\
\text { Immunoglobulin } \\
\text { COVID-19: Oxygen therapy; } \\
\text { Hydroxychloroquine; } \\
\text { Darunavir/cobicistat }\end{array}$ & $\begin{array}{l}\text { Hospitalization: } \\
>21 \text { days } \\
\text { Outcome: Not } \\
\text { reported }\end{array}$ \\
\hline $\begin{array}{l}\text { Vega Hernández, P., et } \\
\text { al. [52] (2020) } \\
\text { Spain } \\
\text { Case report }\end{array}$ & $\begin{array}{l}\text { Female } \\
13\end{array}$ & $\begin{array}{l}\text { COVID-19 } \\
\text { confirmation } \\
\text { test: } \\
\text { Positive rRT- } \\
\text { PCR } \\
\text { COVID-19 } \\
\text { to AD } \\
\text { latency: } \\
0 \text { days }\end{array}$ & $\begin{array}{l}\text { De novo: } \\
\text { Autoimmune } \\
\text { hemolytic anemia } \\
\text { Exacerbation: } \\
\text { Psoriasis } \\
\text { (Status not } \\
\text { specified) }\end{array}$ & $\begin{array}{l}\text { Anemia; Positive } \\
\text { direct Coombs test }\end{array}$ & $\begin{array}{l}\text { AD: Methylprednisolone (pulse } \\
\text { doses); Prednisone }\end{array}$ & $\begin{array}{l}\text { Hospitalization: } \\
14 \text { days } \\
\text { Outcome: } \\
\text { Favorable }\end{array}$ \\
\hline $\begin{array}{l}\text { Yokogawa, N., et } \\
\text { al. [53] (2020) }\end{array}$ & $\begin{array}{c}\text { Male } \\
57\end{array}$ & $\begin{array}{l}\text { COVID-19 } \\
\text { confirmation }\end{array}$ & $\begin{array}{l}\text { De novo: Acute } \\
\text { arthritis }\end{array}$ & - & - & $\begin{array}{l}\text { Hospitalization: } \\
27 \text { days }\end{array}$ \\
\hline
\end{tabular}




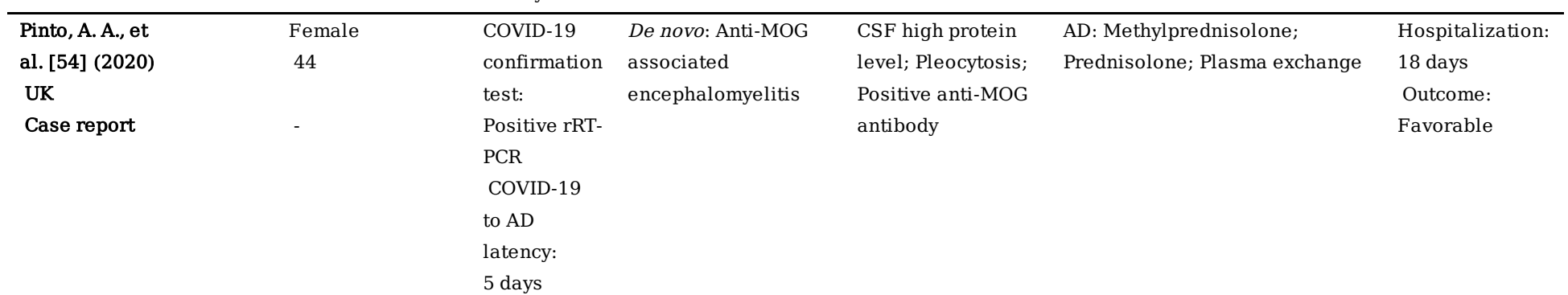

\begin{tabular}{|c|c|c|c|c|c|c|}
\hline $\begin{array}{l}\text { Singh, S. and R. } \\
\text { Govindarajan [55] (2020). } \\
\text { USA } \\
\text { Case report }\end{array}$ & $\begin{array}{l}\text { Female } \\
36 \\
\text { Thymic } \\
\text { hyperplasia }\end{array}$ & $\begin{array}{l}\text { COVID-19 } \\
\text { confirmation } \\
\text { test: } \\
\text { Positive rRT- } \\
\text { PCR } \\
\text { COVID-19 } \\
\text { to AD } \\
\text { latency: } \\
0 \text { days }\end{array}$ & $\begin{array}{l}\text { Exacerbation: } \\
\text { Myasthenia Gravis } \\
\text { (seronegative } \\
\text { generalized) } \\
\text { (Previously in } \\
\text { remission with: } \\
\text { Prednisone; } \\
\text { Mycophenolate } \\
\text { Mofetil; } \\
\text { Pyridostigmine; } \\
\text { Immunoglobulin) }\end{array}$ & - & $\begin{array}{l}\text { AD: Plasmapheresis; Stress } \\
\text { dose IV steroids; Intubation } \\
\text { COVID-19: Supportive care }\end{array}$ & $\begin{array}{l}\text { Hospitalization: } \\
24 \text { days } \\
\text { Outcome: } \\
\text { Favorable }\end{array}$ \\
\hline $\begin{array}{l}\text { Capes, A., et } \\
\text { al. [56] (2020). } \\
\text { Belgium } \\
\text { Case report }\end{array}$ & $\begin{array}{l}\text { Male } \\
62 \\
\text { Hypertension; } \\
\text { Oropharyngeal } \\
\text { squamous cell } \\
\text { carcinoma }\end{array}$ & $\begin{array}{l}\text { COVID-19 } \\
\text { confirmation } \\
\text { test: } \\
\text { Positive rRT- } \\
\text { PCR } \\
\text { COVID-19 } \\
\text { to AD } \\
\text { latency: } \\
16 \text { days }\end{array}$ & $\begin{array}{l}\text { De novo: } \\
\text { Autoimmune } \\
\text { hemolytic anemia }\end{array}$ & $\begin{array}{l}\text { Thrombocytopenia; } \\
\text { Anemia; Positive } \\
\text { ANA; Positive } \\
\text { direct Coombs test }\end{array}$ & $\begin{array}{l}\text { AD: Red blood cell transfusion } \\
\text { COVID-19: Intubation }\end{array}$ & $\begin{array}{l}\text { Hospitalization: } \\
\text { >19 days } \\
\text { ICU admission: } \\
\text { Yes } \\
\text { Outcome: Not } \\
\text { reported }\end{array}$ \\
\hline $\begin{array}{l}\text { Barzegar, M., et } \\
\text { al. [57] (2020) } \\
\text { Iran } \\
\text { Case report }\end{array}$ & $\begin{array}{l}\text { Female } \\
42 \\
\text { Major depression } \\
\text { disorder; } \\
\text { Hypothyroidism; } \\
\text { Pulmonary } \\
\text { embolism }\end{array}$ & $\begin{array}{l}\text { COVID-19 } \\
\text { confirmation } \\
\text { test: } \\
\text { Positive rRT- } \\
\text { PCR } \\
\text { COVID-19 } \\
\text { to AD } \\
\text { latency: } \\
\text { Unclear }\end{array}$ & $\begin{array}{l}\text { Exacerbation: } \\
\text { Multiple sclerosis } \\
\text { (relapsing-remitting), } \\
\text { Myasthenia gravis, } \\
\text { (Previously in } \\
\text { remission with: } \\
\text { Fingolimod) }\end{array}$ & - & $\begin{array}{l}\text { AD: Methylprednisolone; } \\
\text { Glatiramer acetate } \\
\text { COVID-19: Azithromycin; } \\
\text { Ceftriaxone; Oxygen therapy; } \\
\text { Hydroxychloroquine; } \\
\text { Oseltamivir; } \\
\text { Piperacillin/tazobactam }\end{array}$ & $\begin{array}{l}\text { Hospitalization: } \\
13 \text { days } \\
\text { Outcome: } \\
\text { Favorable }\end{array}$ \\
\hline $\begin{array}{l}\text { Murt, A., et al. [58] (2020) } \\
\text { Turkey } \\
\text { Case report }\end{array}$ & $\begin{array}{l}\text { Male } \\
41 \\
-\end{array}$ & $\begin{array}{l}\text { COVID-19 } \\
\text { confirmation } \\
\text { test: } \\
\text { Positive rRT- } \\
\text { PCR } \\
\text { COVID-19 } \\
\text { to AD } \\
\text { latency: } \\
15 \text { days }\end{array}$ & $\begin{array}{l}\text { De novo: Immune } \\
\text { thrombocytopenic } \\
\text { purpura }\end{array}$ & Thrombocytopenia & $\begin{array}{l}\text { AD: Dexamethasone; } \\
\text { Immunoglobulin } \\
\text { COVID-19: Favipiravir }\end{array}$ & $\begin{array}{l}\text { Hospitalization: } \\
\geq 9 \text { days } \\
\text { Outcome: } \\
\text { Favorable }\end{array}$ \\
\hline $\begin{array}{l}\text { Zhao, H., et } \\
\text { al. [59] (2020). } \\
\text { China } \\
\text { Case report }\end{array}$ & $\begin{array}{l}\text { Female } \\
61\end{array}$ & $\begin{array}{l}\text { COVID-19 } \\
\text { confirmation } \\
\text { test: } \\
\text { Positive rRT- } \\
\text { PCR } \\
\text { COVID-19 } \\
\text { to AD } \\
\text { latency: } \\
\leq 3 \text { days }\end{array}$ & $\begin{array}{l}\text { De novo: Guillain- } \\
\text { Barré syndrome }\end{array}$ & $\begin{array}{l}\text { CSF high protein } \\
\text { level }\end{array}$ & $\begin{array}{l}\text { AD: Immunoglobulin } \\
\text { COVID-19: Supportive care; } \\
\text { Umifenovir; Lopinavir/Ritonavir }\end{array}$ & $\begin{array}{l}\text { Hospitalization: } \\
30 \text { days } \\
\text { Outcome: } \\
\text { Favorable }\end{array}$ \\
\hline
\end{tabular}




\begin{tabular}{|c|c|c|c|c|c|c|}
\hline $\begin{array}{l}\text { Padroni, M., et } \\
\text { al. [60] (2020) } \\
\text { Italy } \\
\text { Case report }\end{array}$ & $\begin{array}{l}\text { Female } \\
70\end{array}$ & $\begin{array}{l}\text { COVID-19 } \\
\text { confirmation } \\
\text { test: } \\
\text { Positive rRT- } \\
\text { PCR } \\
\text { COVID-19 } \\
\text { to AD } \\
\text { latency: } \\
23 \text { days }\end{array}$ & $\begin{array}{l}\text { De novo: Guillain- } \\
\text { Barré syndrome } \\
\text { (Acute motor and } \\
\text { sensory axonal } \\
\text { neuropathy) }\end{array}$ & $\begin{array}{l}\text { CSF high protein } \\
\text { level }\end{array}$ & $\begin{array}{l}\text { AD: Immunoglobulin; Intubation; } \\
\text { Mechanical ventilator support }\end{array}$ & $\begin{array}{l}\text { Hospitalization: } \\
>8 \text { days } \\
\text { Outcome: Not } \\
\text { reported }\end{array}$ \\
\hline $\begin{array}{l}\text { Alberti, P., et } \\
\text { al. [61] (2020) } \\
\text { Italy } \\
\text { Case report }\end{array}$ & $\begin{array}{l}\text { Male } \\
71 \\
\text { Hypertension; } \\
\text { Abdominal aortic } \\
\text { aneurysm; Lung } \\
\text { cancer }\end{array}$ & $\begin{array}{l}\text { COVID-19 } \\
\text { confirmation } \\
\text { test: } \\
\text { Positive rRT- } \\
\text { PCR } \\
\text { COVID-19 } \\
\text { to AD } \\
\text { latency: } \\
4 \text { days }\end{array}$ & $\begin{array}{l}\text { De novo: Guillain- } \\
\text { Barré syndrome } \\
\text { (Acute motor and } \\
\text { sensory axonal } \\
\text { neuropathy) }\end{array}$ & $\begin{array}{l}\text { CSF high protein } \\
\text { level; Pleocytosis }\end{array}$ & $\begin{array}{l}\text { AD: Immunoglobulin } \\
\text { COVID-19: Oxygen therapy } \\
\text { (FiO2: 60-80\%); } \\
\text { Lopinavir/Ritonavir; } \\
\text { Hydroxychloroquine; } \\
\text { Mechanical ventilator support } \\
\text { (CPAP); Prone positioning }\end{array}$ & $\begin{array}{l}\text { Hospitalization: } \\
1 \text { day } \\
\text { Outcome: } \\
\text { Death }\end{array}$ \\
\hline $\begin{array}{l}\text { Zulfiqar, A. A., et } \\
\text { al. [62] (2020) } \\
\text { France } \\
\text { Case report }\end{array}$ & $\begin{array}{l}\text { Female } \\
65 \\
\text { Hypertension }\end{array}$ & $\begin{array}{l}\text { COVID-19 } \\
\text { confirmation } \\
\text { test: } \\
\text { Positive rRT- } \\
\text { PCR } \\
\text { COVID-19 } \\
\text { to AD } \\
\text { latency: } \\
8 \text { days }\end{array}$ & $\begin{array}{l}\text { De novo: Immune } \\
\text { thrombocytopenic } \\
\text { purpura } \\
\text { Exacerbation: } \\
\text { Autoimmune } \\
\text { hypothyroidism } \\
\text { (Status not } \\
\text { specified) }\end{array}$ & Thrombocytopenia & $\begin{array}{l}\text { AD: Immunoglobulin; Platelet } \\
\text { transfusions; Prednisolone; } \\
\text { Eltrombopag } \\
\text { COVID-19: Amoxicillin and } \\
\text { clavulanic acid; Low molecular } \\
\text { weight heparin; Oxygen therapy }\end{array}$ & $\begin{array}{l}\text { Hospitalization: } \\
14 \text { days } \\
\text { Outcome: } \\
\text { Favorable }\end{array}$ \\
\hline $\begin{array}{l}\text { Nesr, G., et } \\
\text { al. [63] (2020) } \\
\text { UK } \\
\text { Case report }\end{array}$ & $\begin{array}{l}\text { Female } \\
34 \\
\text { Pregnant (second } \\
\text { trimester) }\end{array}$ & $\begin{array}{l}\text { COVID-19 } \\
\text { confirmation } \\
\text { test: } \\
\text { Positive rRT- } \\
\text { PCR } \\
\text { COVID-19 } \\
\text { to AD } \\
\text { latency: } \\
0 \text { days }\end{array}$ & $\begin{array}{l}\text { Exacerbation: } \\
\text { Immune } \\
\text { thrombocytopenic } \\
\text { purpura } \\
\text { (Previously in } \\
\text { remission) }\end{array}$ & Thrombocytopenia & $\begin{array}{l}\text { AD: Immunoglobulin; } \\
\text { Prednisolone }\end{array}$ & $\begin{array}{l}\text { Hospitalization: } \\
2 \text { days } \\
\text { Outcome: } \\
\text { Favorable }\end{array}$ \\
\hline $\begin{array}{l}\text { Arnaud, S., et } \\
\text { al. [64] (2020) } \\
\text { France } \\
\text { Case report }\end{array}$ & $\begin{array}{l}\text { Male } \\
64 \\
\text { DM (Type 2) }\end{array}$ & $\begin{array}{l}\text { COVID-19 } \\
\text { confirmation } \\
\text { test: } \\
\text { Positive rRT- } \\
\text { PCR } \\
\text { COVID-19 } \\
\text { to AD } \\
\text { latency: } \\
23 \text { days }\end{array}$ & $\begin{array}{l}\text { De novo: Guillain- } \\
\text { Barré syndrome }\end{array}$ & $\begin{array}{l}\text { CSF high protein } \\
\text { level }\end{array}$ & $\begin{array}{l}\text { AD: Immunoglobulin } \\
\text { COVID-19: Cefotaxime; } \\
\text { Azithromycin; } \\
\text { Hydroxychloroquine }\end{array}$ & $\begin{array}{l}\text { Hospitalization: } \\
\geq 27 \text { days } \\
\text { Outcome: } \\
\text { Favorable }\end{array}$ \\
\hline $\begin{array}{l}\text { Ma, J., et al. [65] (2020). } \\
\text { China } \\
\text { Case report }\end{array}$ & $\begin{array}{l}\text { Male } \\
69\end{array}$ & $\begin{array}{l}\text { COVID-19 } \\
\text { confirmation } \\
\text { test: } \\
\text { Positive IgM } \\
\text { and IgG } \\
\text { COVID-19 } \\
\text { to AD } \\
\text { latency: } \\
49 \text { days }\end{array}$ & $\begin{array}{l}\text { De novo: } \\
\text { Antiphospholipid } \\
\text { syndrome }\end{array}$ & $\begin{array}{l}\text { High serum IL-6; } \\
\text { Thrombocytopenia; } \\
\text { Positive anti-beta- } \\
\text { 2-glycoprotein I; } \\
\text { Positive anti- } \\
\text { cardiolipin } \\
\text { antibodies }\end{array}$ & $\begin{array}{l}\text { AD: Low molecular weight } \\
\text { heparin; Aspirin; Plasma } \\
\text { exchange } \\
\text { COVID-19: Antibiotic therapy; } \\
\text { Ribavirin; Intubation; } \\
\text { Mechanical ventilator support } \\
\text { (pressure control (PC) mode; } \\
\text { FiO2: 40\%; PEEP: } 8 \text { cmH2O); } \\
\text { Immunoglobulin; Supportive } \\
\text { care }\end{array}$ & $\begin{array}{l}\text { Hospitalization: } \\
>61 \text { days } \\
\text { ICU admission: } \\
\text { Yes } \\
\text { Outcome: Not } \\
\text { reported }\end{array}$ \\
\hline $\begin{array}{l}\text { Hu, Z., et al. [66] (2020) } \\
\text { China } \\
\text { Case report }\end{array}$ & $\begin{array}{l}\text { Female } \\
72\end{array}$ & $\begin{array}{l}\text { COVID-19 } \\
\text { confirmation } \\
\text { test: } \\
\text { Positive rRT- } \\
\text { PCR } \\
\text { COVID-19 } \\
\text { to AD } \\
\text { latency: }\end{array}$ & $\begin{array}{l}\text { Exacerbation: } \\
\text { Immune } \\
\text { thrombocytopenic } \\
\text { purpura } \\
\text { (Previously in } \\
\text { remission with: } \\
\text { Prednisone; }\end{array}$ & Thrombocytopenia & $\begin{array}{l}\text { AD: Immunoglobulin; Platelet } \\
\text { transfusions; } \\
\text { Methylprednisolone } \\
\text { COVID-19: Umifenovir; } \\
\text { Darunavir/cobicistat }\end{array}$ & $\begin{array}{l}\text { Hospitalization: } \\
29 \text { days } \\
\text { Outcome: } \\
\text { Favorable }\end{array}$ \\
\hline
\end{tabular}




\begin{tabular}{|c|c|c|c|c|c|c|}
\hline & & $\leq 5$ days & $\begin{array}{l}\text { Cyclosporine; } \\
\text { Interferon alfa) }\end{array}$ & & & \\
\hline $\begin{array}{l}\text { Lopez, C., et } \\
\text { al. [67] (2020). } \\
\text { USA } \\
\text { Case report }\end{array}$ & $\begin{array}{l}\text { Female } \\
46 \\
\text { Congenital } \\
\text { thrombocytopenia }\end{array}$ & $\begin{array}{l}\text { COVID-19 } \\
\text { confirmation } \\
\text { test: } \\
\text { Positive rRT- } \\
\text { PCR } \\
\text { COVID-19 } \\
\text { to AD } \\
\text { latency: } \\
4 \text { days }\end{array}$ & $\begin{array}{l}\text { De novo: } \\
\text { Autoimmune } \\
\text { hemolytic anemia } \\
\text { (Warm agglutinin } \\
\text { disease) }\end{array}$ & $\begin{array}{l}\text { Thrombocytopenia; } \\
\text { Anemia; Positive } \\
\text { direct Coombs test }\end{array}$ & $\begin{array}{l}\text { AD: Immunoglobulin; Red blood } \\
\text { cell transfusions; Prednisone } \\
\text { COVID-19: Azithromycin; } \\
\text { Hydroxychloroquine }\end{array}$ & $\begin{array}{l}\text { Hospitalization: } \\
9 \text { days } \\
\text { Outcome: } \\
\text { Favorable }\end{array}$ \\
\hline $\begin{array}{l}\text { Abdi, S., et al. [68] (2020) } \\
\text { Iran } \\
\text { Case report }\end{array}$ & $\begin{array}{l}\text { Male } \\
58 \\
-\end{array}$ & $\begin{array}{l}\text { COVID-19 } \\
\text { confirmation } \\
\text { test: } \\
\text { Positive rRT- } \\
\text { PCR } \\
\text { COVID-19 } \\
\text { to AD } \\
\text { latency: } \\
\text { Unclear }\end{array}$ & $\begin{array}{l}\text { De novo: Acute } \\
\text { disseminated } \\
\text { encephalomyelitis }\end{array}$ & - & AD: Dexamethasone & $\begin{array}{l}\text { Hospitalization: } \\
13 \text { days } \\
\text { ICU admission: } \\
\text { Yes } \\
\text { Outcome: } \\
\text { Death }\end{array}$ \\
\hline $\begin{array}{l}\text { Oriot, P. and M. P. } \\
\text { Hermans [69] (2020) } \\
\text { Belgium } \\
\text { Case report }\end{array}$ & $\begin{array}{l}\text { Male } \\
60 \\
\text { Hypothyroidism; } \\
\text { Obstructive sleep } \\
\text { apnea syndrome }\end{array}$ & $\begin{array}{l}\text { COVID-19 } \\
\text { confirmation } \\
\text { test: } \\
\text { Positive rRT- } \\
\text { PCR } \\
\text { COVID-19 } \\
\text { to AD } \\
\text { latency: } \\
5 \text { days }\end{array}$ & $\begin{array}{l}\text { Exacerbation: Type } 1 \\
\text { diabetes mellitus } \\
\text { (Treated with: } \\
\text { Glargine; Glulisine; } \\
\text { Empagliflozin) }\end{array}$ & - & $\begin{array}{l}\text { AD: Intravenous fluid therapy; } \\
\text { Insulin } \\
\text { COVID-19: Mechanical } \\
\text { ventilator support }\end{array}$ & $\begin{array}{l}\text { Hospitalization: } \\
>43 \text { days } \\
\text { ICU admission: } \\
\text { Yes } \\
\text { Outcome: } \\
\text { Favorable }\end{array}$ \\
\hline $\begin{array}{l}\text { Reyes-Bueno, J. A., et } \\
\text { al. [70] (2020) } \\
\text { Spain } \\
\text { Case report }\end{array}$ & $\begin{array}{l}\text { Female } \\
51 \\
-\end{array}$ & $\begin{array}{l}\text { COVID-19 } \\
\text { confirmation } \\
\text { test: } \\
\text { Negative } \\
\text { rRT-PCR; } \\
\text { Positive IgG } \\
\text { COVID-19 } \\
\text { to AD } \\
\text { latency: } \\
15 \text { days }\end{array}$ & $\begin{array}{l}\text { De novo: Guillain- } \\
\text { Barré syndrome } \\
\text { (Miller Fisher } \\
\text { syndrome) }\end{array}$ & $\begin{array}{l}\text { CSF high protein } \\
\text { level }\end{array}$ & $\begin{array}{l}\text { AD: Immunoglobulin; } \\
\text { Gabapentin }\end{array}$ & $\begin{array}{l}\text { Hospitalization: } \\
\geq 19 \text { days } \\
\text { Outcome: } \\
\text { Favorable }\end{array}$ \\
\hline $\begin{array}{l}\text { Waltuch, T., et } \\
\text { al. [71] (2020) } \\
\text { USA } \\
\text { Case series }\end{array}$ & $\begin{array}{l}\text { Male } \\
13 \\
\text { Hypothyroidism }\end{array}$ & $\begin{array}{l}\text { COVID-19 } \\
\text { confirmation } \\
\text { test: } \\
\text { Negative } \\
\text { rRT-PCR; } \\
\text { Positive IgG } \\
\text { COVID-19 } \\
\text { to AD } \\
\text { latency: } \\
\text { Unclear }\end{array}$ & De novo: MIS-C & $\begin{array}{l}\text { High serum IL-6; } \\
\text { High serum IL-8; } \\
\text { High serum TNF- } \alpha\end{array}$ & $\begin{array}{l}\text { AD: Intravenous fluid therapy; } \\
\text { Meropenem; Linezolid; } \\
\text { Immunoglobulin; Tocilizumab; } \\
\text { Anakinra } \\
\text { COVID-19: Intubation; } \\
\text { Enoxaparin }\end{array}$ & $\begin{array}{l}\text { Hospitalization: } \\
\text { >2 days } \\
\text { ICU admission: } \\
\text { Yes } \\
\text { Outcome: Not } \\
\text { reported }\end{array}$ \\
\hline & $\begin{array}{l}\text { Male } \\
10 \\
\text { Asthma }\end{array}$ & $\begin{array}{l}\text { COVID-19 } \\
\text { confirmation } \\
\text { test: } \\
\text { Positive rRT- } \\
\text { PCR } \\
\text { COVID-19 } \\
\text { to AD } \\
\text { latency: } \\
12 \text { days }\end{array}$ & De novo: MIS-C & $\begin{array}{l}\text { High serum IL-6; } \\
\text { High serum IL-8; } \\
\text { High serum TNF- } \alpha\end{array}$ & $\begin{array}{l}\text { AD: Intravenous fluid therapy; } \\
\text { Cefepime; Clindamycin; } \\
\text { Dopamine; Immunoglobulin; } \\
\text { Tocilizumab; Linezolid }\end{array}$ & $\begin{array}{l}\text { Hospitalization: } \\
\text { unknown } \\
\text { duration } \\
\text { ICU admission: } \\
\text { Yes } \\
\text { Outcome: Not } \\
\text { reported }\end{array}$ \\
\hline & $\begin{array}{l}\text { Male } \\
5\end{array}$ & $\begin{array}{l}\text { COVID-19 } \\
\text { confirmation } \\
\text { test: } \\
\text { Negative }\end{array}$ & De novo: MIS-C & $\begin{array}{l}\text { High serum IL-6; } \\
\text { High serum IL-8; } \\
\text { High serum TNF- } \alpha\end{array}$ & $\begin{array}{l}\text { AD: Intravenous fluid therapy; } \\
\text { Ceftriaxone; Clindamycin; } \\
\text { Enoxaparin; Dopamine; } \\
\text { Immunoglobulin; Tocilizumab }\end{array}$ & $\begin{array}{l}\text { Hospitalization: } \\
>3 \text { days } \\
\text { ICU admission: } \\
\text { Yes }\end{array}$ \\
\hline
\end{tabular}




\begin{tabular}{|c|c|c|c|c|c|c|}
\hline & $\begin{array}{l}\text { Female } \\
12 \\
-\end{array}$ & $\begin{array}{l}\text { COVID-19 } \\
\text { confirmation } \\
\text { test: } \\
\text { Negative } \\
\text { rRT-PCR; } \\
\text { Positive IgG } \\
\text { COVID-19 } \\
\text { to AD } \\
\text { latency: } \\
\text { Unclear }\end{array}$ & De novo: MIS-C & $\begin{array}{l}\text { High serum IL-6; } \\
\text { High serum IL-8; } \\
\text { High serum TNF- } \alpha\end{array}$ & $\begin{array}{l}\text { AD: Intravenous fluid therapy; } \\
\text { Cefepime; Vancomycin; } \\
\text { Metronidazole }\end{array}$ & $\begin{array}{l}\text { Hospitalization: } \\
\text { unknown } \\
\text { duration } \\
\text { ICU admission: } \\
\text { Yes } \\
\text { Outcome: Not } \\
\text { reported }\end{array}$ \\
\hline $\begin{array}{l}\text { Sokolovsky, S., et } \\
\text { al. [72] (2020) } \\
\text { USA } \\
\text { Case report }\end{array}$ & $\begin{array}{l}\text { Female } \\
36 \\
-\end{array}$ & $\begin{array}{l}\text { COVID-19 } \\
\text { confirmation } \\
\text { test: } \\
\text { Positive rRT- } \\
\text { PCR } \\
\text { COVID-19 } \\
\text { to AD } \\
\text { latency: } \\
5 \text { days }\end{array}$ & De novo: MIS-A & $\begin{array}{l}\text { Positive ANA; } \\
\text { Positive anti- } \\
\text { Ro/SSA; Low } \\
\text { complement C3 } \\
\text { and C4 }\end{array}$ & $\begin{array}{l}\text { AD: Intravenous fluid therapy; } \\
\text { Aspirin; Immunoglobulin; } \\
\text { Methylprednisolone; Prednisone }\end{array}$ & $\begin{array}{l}\text { Hospitalization: } \\
6 \text { days } \\
\text { Outcome: } \\
\text { Favorable }\end{array}$ \\
\hline $\begin{array}{l}\text { Albiol, N., et } \\
\text { al. [73] (2020) } \\
\text { Spain } \\
\text { Case report }\end{array}$ & $\begin{array}{l}\text { Female } \\
57 \\
\text { Hypertension; } \\
\text { Breast cancer }\end{array}$ & $\begin{array}{l}\text { COVID-19 } \\
\text { confirmation } \\
\text { test: } \\
\text { Negative } \\
\text { rRT-PCR; } \\
\text { Positive IgG } \\
\text { COVID-19 } \\
\text { to AD } \\
\text { latency: } \\
6 \text { days }\end{array}$ & $\begin{array}{l}\text { De novo: } \\
\text { Autoimmune } \\
\text { thrombotic } \\
\text { thrombocytopenic } \\
\text { purpura }\end{array}$ & $\begin{array}{l}\text { Thrombocytopenia; } \\
\text { Anemia; Positive } \\
\text { ADAMTS-13 } \\
\text { inhibitor }\end{array}$ & $\begin{array}{l}\text { AD: Methylprednisolone; } \\
\text { Immunoglobulin; Plasma } \\
\text { infusion; Plasma exchange } \\
\text { COVID-19: Lopinavir/Ritonavir; } \\
\text { Hydroxychloroquine; } \\
\text { Azithromycin }\end{array}$ & $\begin{array}{l}\text { Hospitalization: } \\
17 \text { days } \\
\text { Outcome: } \\
\text { Favorable }\end{array}$ \\
\hline $\begin{array}{l}\text { Chiotos, K., et } \\
\text { al. [74] (2020). } \\
\text { USA } \\
\text { Case series }\end{array}$ & $\begin{array}{l}\text { Female } \\
14 \\
-\end{array}$ & $\begin{array}{l}\text { COVID-19 } \\
\text { confirmation } \\
\text { test: } \\
\text { Negative } \\
\text { rRT-PCR; } \\
\text { Positive IgG } \\
\text { COVID-19 } \\
\text { to AD } \\
\text { latency: } \\
\text { Unclear }\end{array}$ & De novo: MIS-C & - & $\begin{array}{l}\text { AD: Epinephrine; } \\
\text { Norepinephrine; Vancomycin; } \\
\text { Cefepime; Clindamycin; } \\
\text { Doxycycline; Immunoglobulin; } \\
\text { Methylprednisolone; Aspirin } \\
\text { COVID-19: Intubation; } \\
\text { Mechanical ventilator support }\end{array}$ & $\begin{array}{l}\text { Hospitalization: } \\
17 \text { days } \\
\text { ICU admission: } \\
\text { Yes } \\
\text { Outcome: } \\
\text { Favorable }\end{array}$ \\
\hline & $\begin{array}{l}\text { Male } \\
12 \\
-\end{array}$ & $\begin{array}{l}\text { COVID-19 } \\
\text { confirmation } \\
\text { test: } \\
\text { Negative } \\
\text { rRT-PCR; } \\
\text { Positive IgG } \\
\text { COVID-19 } \\
\text { to AD } \\
\text { latency: } \\
\text { Unclear }\end{array}$ & De novo: MIS-C & - & $\begin{array}{l}\text { AD: Milrinone; Epinephrine; } \\
\text { Vasopressin; } \\
\text { Methylprednisolone (pulse } \\
\text { dose); Immunoglobulin; } \\
\text { Vancomycin; Cefepime; } \\
\text { Clindamycin } \\
\text { COVID-19: Mechanical } \\
\text { ventilator support }\end{array}$ & $\begin{array}{l}\text { Hospitalization: } \\
12 \text { days } \\
\text { ICU admission: } \\
\text { Yes } \\
\text { Outcome: } \\
\text { Favorable }\end{array}$ \\
\hline & $\begin{array}{l}\text { Female } \\
9 \\
-\end{array}$ & $\begin{array}{l}\text { COVID-19 } \\
\text { confirmation } \\
\text { test: } \\
\text { Positive rRT- } \\
\text { PCR } \\
\text { COVID-19 } \\
\text { to AD }\end{array}$ & De novo: MIS-C & - & $\begin{array}{l}\text { AD: Intravenous fluid therapy; } \\
\text { Immunoglobulin; } \\
\text { Methylprednisolone; Aspirin; } \\
\text { Mechanical ventilator support; } \\
\text { Furosemide; } \\
\text { Piperacillin/tazobactam; } \\
\text { Ciprofloxacin; Vancomycin }\end{array}$ & $\begin{array}{l}\text { Hospitalization: } \\
8 \text { days } \\
\text { ICU admission: } \\
\text { Yes } \\
\text { Outcome: } \\
\text { Favorable }\end{array}$ \\
\hline
\end{tabular}




\begin{tabular}{|c|c|c|c|c|c|}
\hline $\begin{array}{l}\text { Female } \\
5\end{array}$ & $\begin{array}{l}\text { COVID-19 } \\
\text { confirmation } \\
\text { test: } \\
\text { Positive rRT- } \\
\text { PCR } \\
\text { COVID-19 } \\
\text { to AD } \\
\text { latency: } \\
0 \text { days }\end{array}$ & De novo: MIS-C & Pleocytosis & $\begin{array}{l}\text { AD: Epinephrine; Milrinone; } \\
\text { Immunoglobulin; } \\
\text { Methylprednisolone; Anakinra; } \\
\text { Methylprednisolone (pulse } \\
\text { dose); Vancomycin; Cefepime; } \\
\text { Ceftriaxone } \\
\text { COVID-19: Intubation; } \\
\text { Mechanical ventilator support }\end{array}$ & $\begin{array}{l}\text { Hospitalization: } \\
11 \text { days } \\
\text { ICU admission: } \\
\text { Yes } \\
\text { Outcome: } \\
\text { Favorable }\end{array}$ \\
\hline $\begin{array}{l}\text { Female } \\
5\end{array}$ & $\begin{array}{l}\text { COVID-19 } \\
\text { confirmation } \\
\text { test: } \\
\text { Negative } \\
\text { rRT-PCR; } \\
\text { Positive IgG } \\
\text { COVID-19 } \\
\text { to AD } \\
\text { latency: } \\
\text { Unclear }\end{array}$ & De novo: MIS-C & - & $\begin{array}{l}\text { AD: Dopamine; Epinephrine; } \\
\text { Immunoglobulin; } \\
\text { Methylprednisolone; Aspirin; } \\
\text { Vancomycin; Cefepime }\end{array}$ & $\begin{array}{l}\text { Hospitalization: } \\
11 \text { days } \\
\text { ICU admission: } \\
\text { Yes } \\
\text { Outcome: } \\
\text { Favorable }\end{array}$ \\
\hline $\begin{array}{l}\text { Female } \\
6\end{array}$ & $\begin{array}{l}\text { COVID-19 } \\
\text { confirmation } \\
\text { test: } \\
\text { Positive rRT- } \\
\text { PCR } \\
\text { COVID-19 } \\
\text { to AD } \\
\text { latency: } \\
0 \text { days }\end{array}$ & De novo: MIS-C & - & $\begin{array}{l}\text { AD: Norepinephrine; Dopamine; } \\
\text { Epinephrine; Milrinone; } \\
\text { Immunoglobulin; } \\
\text { Methylprednisolone; } \\
\text { Methylprednisolone (pulse } \\
\text { dose); Vancomycin; Ceftriaxone; } \\
\text { Metronidazole } \\
\text { COVID-19: Intubation; } \\
\text { Mechanical ventilator support }\end{array}$ & $\begin{array}{l}\text { Hospitalization: } \\
>7 \text { days } \\
\text { ICU admission: } \\
\text { Yes } \\
\text { Outcome: Not } \\
\text { reported }\end{array}$ \\
\hline $\begin{array}{l}\text { Female } \\
71 \\
\end{array}$ & $\begin{array}{l}\text { COVID-19 } \\
\text { confirmation } \\
\text { test: } \\
\text { Unclear } \\
\text { COVID-19 } \\
\text { to AD } \\
\text { latency: } \\
4 \text { days }\end{array}$ & $\begin{array}{l}\text { Exacerbation: } \\
\text { Psoriasis } \\
\text { (Previously in } \\
\text { remission) }\end{array}$ & - & $\begin{array}{l}\text { COVID-19: Oseltamivir; } \\
\text { Hydroxychloroquine }\end{array}$ & $\begin{array}{l}\text { Hospitalization: } \\
>4 \text { days } \\
\text { Outcome: Not } \\
\text { reported }\end{array}$ \\
\hline $\begin{array}{l}\text { Female } \\
32\end{array}$ & $\begin{array}{l}\text { COVID-19 } \\
\text { confirmation } \\
\text { test: } \\
\text { Positive rRT- } \\
\text { PCR } \\
\text { COVID-19 } \\
\text { to AD } \\
\text { latency: } \\
\text { Unclear }\end{array}$ & $\begin{array}{l}\text { Exacerbation: } \\
\text { Autoimmune } \\
\text { polyglandular } \\
\text { syndrome type } 1 \\
\text { (hypoparathyroidism) } \\
\text { (Previously in } \\
\text { remission with: } \\
\text { rhPTH (1-84); } \\
\text { Glucocorticoid) }\end{array}$ & - & $\begin{array}{l}\text { AD: Calcitriol; Calcium } \\
\text { supplementation } \\
\text { COVID-19: Oxygen therapy; } \\
\text { Intubation; Mechanical } \\
\text { ventilator support; } \\
\text { Lopinavir/Ritonavir; Ribavirin; } \\
\text { Hydroxychloroquine; } \\
\text { Azithromycin; } \\
\text { Piperacillin/tazobactam; } \\
\text { Trimethoprim/sulfamethoxazole; } \\
\text { Norepinephrine; Dobutamine; } \\
\text { Hydrocortisone }\end{array}$ & $\begin{array}{l}\text { Hospitalization: } \\
37 \text { days } \\
\text { ICU admission: } \\
\text { Yes } \\
\text { Outcome: } \\
\text { Favorable }\end{array}$ \\
\hline $\begin{array}{l}\text { Male } \\
69 \\
\text { Hypertension; } \\
\text { DM; Stroke }\end{array}$ & $\begin{array}{l}\text { COVID-19 } \\
\text { confirmation } \\
\text { test: } \\
\text { Positive rRT- } \\
\text { PCR } \\
\text { COVID-19 } \\
\text { to AD } \\
\text { latency: } \\
18 \text { days }\end{array}$ & $\begin{array}{l}\text { De novo: } \\
\text { Antiphospholipid } \\
\text { syndrome }\end{array}$ & $\begin{array}{l}\text { Thrombocytopenia; } \\
\text { Anemia; Positive } \\
\text { anti-beta-2- } \\
\text { glycoprotein I; } \\
\text { Positive anti- } \\
\text { cardiolipin } \\
\text { antibodies }\end{array}$ & $\begin{array}{l}\text { AD: Immunoglobulin } \\
\text { COVID-19: Mechanical } \\
\text { ventilator support; Oseltamivir }\end{array}$ & $\begin{array}{l}\text { Hospitalization: } \\
>24 \text { days } \\
\text { ICU admission: } \\
\text { Yes } \\
\text { Outcome: Not } \\
\text { reported }\end{array}$ \\
\hline $\begin{array}{l}\text { Female } \\
65 \\
\text { Hypertension; }\end{array}$ & $\begin{array}{l}\text { COVID-19 } \\
\text { confirmation } \\
\text { test: } \\
\text { Unclear }\end{array}$ & $\begin{array}{l}\text { De novo: } \\
\text { Antiphospholipid } \\
\text { syndrome }\end{array}$ & $\begin{array}{l}\text { Thrombocytopenia; } \\
\text { Anemia; Positive } \\
\text { anti-beta-2- } \\
\text { glycoprotein I; }\end{array}$ & COVID-19: Antibiotic therapy & $\begin{array}{l}\text { Hospitalization: } \\
>33 \text { days } \\
\text { ICU admission: } \\
\text { Yes }\end{array}$ \\
\hline
\end{tabular}




\begin{tabular}{|c|c|c|c|c|c|c|}
\hline & $\begin{array}{l}\mathrm{DM} \text {; Coronary } \\
\text { artery disease }\end{array}$ & $\begin{array}{l}\text { COVID-19 } \\
\text { to } \mathrm{AD} \\
\text { latency: } \\
33 \text { days }\end{array}$ & & $\begin{array}{l}\text { Positive anti- } \\
\text { cardiolipin } \\
\text { antibodies }\end{array}$ & & $\begin{array}{l}\text { Outcome: Not } \\
\text { reported }\end{array}$ \\
\hline & $\begin{array}{l}\text { Male } \\
70 \\
\text { Hypertension; } \\
\text { Emphysema; } \\
\text { Nasopharyngeal } \\
\text { carcinoma; } \\
\text { Stroke }\end{array}$ & $\begin{array}{l}\text { COVID-19 } \\
\text { confirmation } \\
\text { test: } \\
\text { Unclear } \\
\text { COVID-19 } \\
\text { to AD } \\
\text { latency: } \\
10 \text { days }\end{array}$ & $\begin{array}{l}\text { De novo: } \\
\text { Antiphospholipid } \\
\text { syndrome }\end{array}$ & $\begin{array}{l}\text { Anemia; Positive } \\
\text { anti-beta-2- } \\
\text { glycoprotein I; } \\
\text { Positive anti- } \\
\text { cardiolipin } \\
\text { antibodies }\end{array}$ & $\begin{array}{l}\text { COVID-19: Antibiotic therapy; } \\
\text { Ribavirin }\end{array}$ & $\begin{array}{l}\text { Hospitalization: } \\
\text { >24 days } \\
\text { ICU admission: } \\
\text { Yes } \\
\text { Outcome: Not } \\
\text { reported }\end{array}$ \\
\hline $\begin{array}{l}\text { Brun, G., et al. [78] (2020) } \\
\text { France } \\
\text { Case report }\end{array}$ & $\begin{array}{l}\text { Female } \\
54 \\
\text { Hypertension }\end{array}$ & $\begin{array}{l}\text { COVID-19 } \\
\text { confirmation } \\
\text { test: } \\
\text { Positive rRT- } \\
\text { PCR } \\
\text { COVID-19 } \\
\text { to AD } \\
\text { latency: } \\
10 \text { days }\end{array}$ & $\begin{array}{l}\text { De novo: CNS } \\
\text { vasculitis }\end{array}$ & - & $\begin{array}{l}\text { AD: Steroid } \\
\text { COVID-19: Intubation; } \\
\text { Mechanical ventilator support; } \\
\text { Prone positioning; } \\
\text { Hydroxychloroquine; } \\
\text { Azithromycin; Amoxicillin and } \\
\text { clavulanic acid }\end{array}$ & $\begin{array}{l}\text { Hospitalization: } \\
>12 \text { days } \\
\text { Outcome: Not } \\
\text { reported }\end{array}$ \\
\hline $\begin{array}{l}\text { Bruni, A., et } \\
\text { al. [79] (2020) } \\
\text { Italy } \\
\text { Case report }\end{array}$ & $\begin{array}{l}\text { Male } \\
59\end{array}$ & $\begin{array}{l}\text { COVID-19 } \\
\text { confirmation } \\
\text { test: } \\
\text { Positive rRT- } \\
\text { PCR } \\
\text { COVID-19 } \\
\text { to AD } \\
\text { latency: } \\
44 \text { days }\end{array}$ & $\begin{array}{l}\text { De novo: Gallbladder } \\
\text { vasculitis }\end{array}$ & $\begin{array}{l}\text { High serum IL-6; } \\
\text { Thrombocytopenia }\end{array}$ & $\begin{array}{l}\text { AD: Meropenem; Tigecycline; } \\
\text { Laparotomic cholecystectomy } \\
\text { COVID-19: Tocilizumab; Oxygen } \\
\text { therapy; Prone positioning; } \\
\text { Intubation; Mechanical } \\
\text { ventilator support; Rocuronium; } \\
\text { Intravenous fluid therapy; } \\
\text { Norepinephrine; Azithromycin; } \\
\text { Hydroxychloroquine; } \\
\text { Enoxaparin }\end{array}$ & $\begin{array}{l}\text { Hospitalization: } \\
>44 \text { days } \\
\text { ICU admission: } \\
\text { Yes } \\
\text { Outcome: } \\
\text { Favorable }\end{array}$ \\
\hline $\begin{array}{l}\text { Reichard, R. R., et } \\
\text { al. [80] (2020) } \\
\text { USA } \\
\text { Case report }\end{array}$ & $\begin{array}{l}\text { Male } \\
71 \\
\text { Myocardial } \\
\text { infarction }\end{array}$ & $\begin{array}{l}\text { COVID-19 } \\
\text { confirmation } \\
\text { test: } \\
\text { Positive rRT- } \\
\text { PCR } \\
\text { COVID-19 } \\
\text { to AD } \\
\text { latency: } \\
\text { Unclear }\end{array}$ & $\begin{array}{l}\text { De novo: Acute } \\
\text { disseminated } \\
\text { encephalomyelitis }\end{array}$ & High serum IL-6 & $\begin{array}{l}\text { COVID-19: Oxygen therapy; } \\
\text { Intubation; Prone positioning; } \\
\text { Sedation/paralysis; Vasopressor } \\
\text { support; Stress dose IV steroids }\end{array}$ & $\begin{array}{l}\text { Hospitalization: } \\
\text { >13 days } \\
\text { Outcome: } \\
\text { Death }\end{array}$ \\
\hline $\begin{array}{l}\text { Verheyden, M., et } \\
\text { al. [81] (2020) } \\
\text { Belgium } \\
\text { Case report }\end{array}$ & $\begin{array}{l}\text { Male } \\
57\end{array}$ & $\begin{array}{l}\text { COVID-19 } \\
\text { confirmation } \\
\text { test: } \\
\text { Positive rRT- } \\
\text { PCR } \\
\text { COVID-19 } \\
\text { to AD } \\
\text { latency: } \\
8 \text { days }\end{array}$ & $\begin{array}{l}\text { De novo: Livedo } \\
\text { reticularis }\end{array}$ & Positive ANA & $\begin{array}{l}\text { AD: Low molecular weight } \\
\text { heparin } \\
\text { COVID-19: Oxygen therapy; } \\
\text { Paracetamol; } \\
\text { Hydroxychloroquine }\end{array}$ & $\begin{array}{l}\text { Hospitalization: } \\
8 \text { days } \\
\text { Outcome: } \\
\text { Favorable }\end{array}$ \\
\hline $\begin{array}{l}\text { Pilotto, A., et } \\
\text { al. [82] (2020) } \\
\text { Italy } \\
\text { Case report }\end{array}$ & $\begin{array}{l}\text { Male } \\
60\end{array}$ & $\begin{array}{l}\text { COVID-19 } \\
\text { confirmation } \\
\text { test: } \\
\text { Positive rRT- } \\
\text { PCR } \\
\text { COVID-19 } \\
\text { to AD } \\
\text { latency: } \\
0 \text { days }\end{array}$ & $\begin{array}{l}\text { De novo: } \\
\text { Encephalitis }\end{array}$ & $\begin{array}{l}\text { CSF high protein } \\
\text { level; High CSF IL- } \\
\text { 6; High CSF IL-8; } \\
\text { High CSF TNF- } \alpha \text {; } \\
\text { High CSF } \beta 2- \\
\text { microglobulin }\end{array}$ & $\begin{array}{l}\text { AD: Ampicillin; Acyclovir; } \\
\text { Methylprednisolone; Prednisone } \\
\text { COVID-19: Lopinavir/Ritonavir; } \\
\text { Hydroxychloroquine }\end{array}$ & $\begin{array}{l}\text { Hospitalization: } \\
11 \text { days } \\
\text { Outcome: } \\
\text { Favorable }\end{array}$ \\
\hline $\begin{array}{l}\text { Wei, H., et al. [83] (2020) } \\
\text { China } \\
\text { Case report }\end{array}$ & DM (Type 2); & $\begin{array}{l}\text { COVID-19 } \\
\text { confirmation } \\
\text { test: } \\
\text { Positive rRT- }\end{array}$ & $\begin{array}{l}\text { De novo: Oculomotor } \\
\text { nerve palsy }\end{array}$ & - & $\begin{array}{l}\text { AD: Methylprednisolone; } \\
\text { Immunoglobulin } \\
\text { COVID-19: Oxygen therapy; } \\
\text { Moxifloxacin; Oseltamivir; }\end{array}$ & $\begin{array}{l}\text { Hospitalization: } \\
12 \text { days } \\
\text { Outcome: } \\
\text { Death }\end{array}$ \\
\hline
\end{tabular}




\begin{tabular}{|c|c|c|c|c|c|c|}
\hline & $\begin{array}{l}\text { Hypertension; } \\
\text { Lacunar } \\
\text { infarction }\end{array}$ & $\begin{array}{l}\text { PCR } \\
\text { COVID-19 } \\
\text { to AD } \\
\text { latency: } \\
\text { Unclear }\end{array}$ & & & $\begin{array}{l}\text { Ribavirin; Lopinavir; } \\
\text { Paracetamol; Iboprufen }\end{array}$ & \\
\hline $\begin{array}{l}\text { Rosen, M. H., et } \\
\text { al. [84] (2020) } \\
\text { USA } \\
\text { Case report }\end{array}$ & $\begin{array}{l}\text { Female } \\
26 \\
-\end{array}$ & $\begin{array}{l}\text { COVID-19 } \\
\text { confirmation } \\
\text { test: } \\
\text { Positive rRT- } \\
\text { PCR } \\
\text { COVID-19 } \\
\text { to AD } \\
\text { latency: } \\
\text { Unclear }\end{array}$ & $\begin{array}{l}\text { Exacerbation: } \\
\text { Ulcerative colitis } \\
\text { (pancolitis) } \\
\text { (Previously in } \\
\text { remission) }\end{array}$ & & $\begin{array}{l}\text { AD: Methylprednisolone; } \\
\text { Prednisone; Cyclosporine } \\
\text { COVID-19: Azithromycin; } \\
\text { Hydroxychloroquine }\end{array}$ & $\begin{array}{l}\text { Hospitalization: } \\
16 \text { days } \\
\text { Outcome: } \\
\text { Favorable }\end{array}$ \\
\hline $\begin{array}{l}\text { Cerasti, D., et } \\
\text { al. [85] (2020) } \\
\text { Italy } \\
\text { Case report }\end{array}$ & $\begin{array}{l}\text { Female } \\
47 \\
\text { Obesity }\end{array}$ & $\begin{array}{l}\text { COVID-19 } \\
\text { confirmation } \\
\text { test: } \\
\text { Positive rRT- } \\
\text { PCR } \\
\text { COVID-19 } \\
\text { to AD } \\
\text { latency: } \\
14 \text { days }\end{array}$ & $\begin{array}{l}\text { Exacerbation: } \\
\text { Antiphospholipid } \\
\text { syndrome } \\
\text { (Status not } \\
\text { specified) }\end{array}$ & & $\begin{array}{l}\text { COVID-19: Ganciclovir; } \\
\text { Oseltamivir; Darunavir; } \\
\text { Cobicistat; Meropenem; } \\
\text { Linezolid; Supportive care; } \\
\text { Intubation }\end{array}$ & $\begin{array}{l}\text { Hospitalization: } \\
9 \text { days } \\
\text { Outcome: } \\
\text { Death }\end{array}$ \\
\hline $\begin{array}{l}\text { Lee, J. M. and S. J. } \\
\text { Lee [86] (2020) } \\
\text { South Korea } \\
\text { Case report }\end{array}$ & $\begin{array}{l}\text { Female } \\
53 \\
-\end{array}$ & $\begin{array}{l}\text { COVID-19 } \\
\text { confirmation } \\
\text { test: } \\
\text { Unclear } \\
\text { COVID-19 } \\
\text { to AD } \\
\text { latency: } \\
22 \text { days }\end{array}$ & $\begin{array}{l}\text { Exacerbation: } \\
\text { Ankylosing } \\
\text { spondylitis } \\
\text { exacerbation } \\
\text { (Previously in } \\
\text { remission with: } \\
\text { Etanercept; } \\
\text { Methotrexate) }\end{array}$ & & AD: Etanercept & $\begin{array}{l}\text { No admission } \\
\text { Outcome: } \\
\text { Favorable }\end{array}$ \\
\hline $\begin{array}{l}\text { Arca, K. N. and A.J. } \\
\text { Starling [87] (2020) } \\
\text { USA } \\
\text { Case report }\end{array}$ & $\begin{array}{l}\text { Female } \\
58 \\
\text { Chronic } \\
\text { migraine; Stroke; } \\
\text { Restless leg } \\
\text { syndrome }\end{array}$ & $\begin{array}{l}\text { COVID-19 } \\
\text { confirmation } \\
\text { test: } \\
\text { Unclear } \\
\text { COVID-19 } \\
\text { to AD } \\
\text { latency: } \\
\text { Unclear }\end{array}$ & $\begin{array}{l}\text { Exacerbation: } \\
\text { Multiple sclerosis } \\
\text { (Previously in } \\
\text { remission with: } \\
\text { Fingolimod) }\end{array}$ & _ & $\begin{array}{l}\text { COVID-19: Hydroxychloroquine; } \\
\text { Azithromycin; Intubation }\end{array}$ & $\begin{array}{l}\text { Hospitalization: } \\
\text { unknown } \\
\text { duration } \\
\text { ICU admission: } \\
\text { Yes } \\
\text { Outcome: } \\
\text { Favorable }\end{array}$ \\
\hline $\begin{array}{l}\text { Zoghi, A., et } \\
\text { al. [88] (2020) } \\
\text { Iran } \\
\text { Case report }\end{array}$ & $\begin{array}{l}\text { Male } \\
21 \\
-\end{array}$ & $\begin{array}{l}\text { COVID-19 } \\
\text { confirmation } \\
\text { test: } \\
\text { Negative } \\
\text { rRT-PCR; } \\
\text { Positive IgG } \\
\text { COVID-19 } \\
\text { to AD } \\
\text { latency: } \\
10 \text { days }\end{array}$ & $\begin{array}{l}\text { De novo: Acute } \\
\text { disseminated } \\
\text { encephalomyelitis }\end{array}$ & $\begin{array}{l}\text { CSF high protein } \\
\text { level; Pleocytosis }\end{array}$ & $\begin{array}{l}\text { AD: Plasma exchange; } \\
\text { Vancomycin; Meropenem; } \\
\text { Acyclovir }\end{array}$ & $\begin{array}{l}\text { Hospitalization: } \\
14 \text { days } \\
\text { ICU admission: } \\
\text { Yes } \\
\text { Outcome: } \\
\text { Favorable }\end{array}$ \\
\hline $\begin{array}{l}\text { Anand, P., et } \\
\text { al. [89] (2020) } \\
\text { USA } \\
\text { Case series }\end{array}$ & $\begin{array}{l}\text { Female } \\
42 \\
\text { Hepatitis B }\end{array}$ & $\begin{array}{l}\text { COVID-19 } \\
\text { confirmation } \\
\text { test: } \\
\text { Positive rRT- } \\
\text { PCR } \\
\text { COVID-19 } \\
\text { to AD } \\
\text { latency: } \\
0 \text { days }\end{array}$ & $\begin{array}{l}\text { Exacerbation: } \\
\text { Myasthenia Gravis } \\
\text { (MuSK+) } \\
\text { (Previously in } \\
\text { remission with: } \\
\text { Prednisone) }\end{array}$ & & $\begin{array}{l}\text { AD: Prednisone; } \\
\text { Immunoglobulin }\end{array}$ & $\begin{array}{l}\text { Hospitalization: } \\
5 \text { days } \\
\text { Outcome: } \\
\text { Favorable }\end{array}$ \\
\hline $\begin{array}{l}\text { Dogan, L., et } \\
\text { al. [90] (2020) } \\
\text { Turkey } \\
\text { Case series }\end{array}$ & $\begin{array}{l}\text { Male } \\
49\end{array}$ & $\begin{array}{l}\text { COVID-19 } \\
\text { confirmation } \\
\text { test: } \\
\text { Positive rRT- }\end{array}$ & $\begin{array}{l}\text { De novo: } \\
\text { Autoimmune } \\
\text { meningoencephalitis }\end{array}$ & High serum IL-6 & $\begin{array}{l}\text { AD: Plasmapheresis } \\
\text { COVID-19: Intubation; } \\
\text { Mechanical ventilator support; } \\
\text { Prone positioning; }\end{array}$ & $\begin{array}{l}\text { Hospitalization: } \\
34 \text { days } \\
\text { ICU admission: } \\
\text { Yes }\end{array}$ \\
\hline
\end{tabular}


PCR

COVID-19

to $\mathrm{AD}$

latency:

13 days

\begin{tabular}{|c|c|c|c|c|c|}
\hline & $\begin{array}{l}\text { latency: } \\
13 \text { days }\end{array}$ & & & & \\
\hline $\begin{array}{l}\text { Male } \\
59 \\
\text { Hypertension }\end{array}$ & $\begin{array}{l}\text { COVID-19 } \\
\text { confirmation } \\
\text { test: } \\
\text { Positive rRT- } \\
\text { PCR } \\
\text { COVID-19 } \\
\text { to AD } \\
\text { latency: } \\
15 \text { days }\end{array}$ & $\begin{array}{l}\text { De novo: } \\
\text { Autoimmune } \\
\text { meningoencephalitis }\end{array}$ & $\begin{array}{l}\text { CSF high protein } \\
\text { level }\end{array}$ & $\begin{array}{l}\text { AD: Plasmapheresis } \\
\text { COVID-19: Intubation; } \\
\text { Mechanical ventilator support; } \\
\text { Prone positioning; Azithromycin; } \\
\text { Hydroxychloroquine; Favipiravir }\end{array}$ & $\begin{array}{l}\text { Hospitalization: } \\
39 \text { days } \\
\text { ICU admission: } \\
\text { Yes } \\
\text { Outcome: } \\
\text { Favorable }\end{array}$ \\
\hline $\begin{array}{l}\text { Male } \\
59 \\
\text { Hypertension; } \\
\text { DM; Obesity }\end{array}$ & $\begin{array}{l}\text { COVID-19 } \\
\text { confirmation } \\
\text { test: } \\
\text { Positive rRT- } \\
\text { PCR } \\
\text { COVID-19 } \\
\text { to AD } \\
\text { latency: } \\
15 \text { days }\end{array}$ & $\begin{array}{l}\text { De novo: } \\
\text { Autoimmune } \\
\text { meningoencephalitis }\end{array}$ & $\begin{array}{l}\text { CSF high protein } \\
\text { level }\end{array}$ & $\begin{array}{l}\text { AD: Plasmapheresis } \\
\text { COVID-19: Intubation; } \\
\text { Mechanical ventilator support; } \\
\text { Prone positioning; Azithromycin; } \\
\text { Hydroxychloroquine; Favipiravir }\end{array}$ & $\begin{array}{l}\text { Hospitalization: } \\
23 \text { days } \\
\text { ICU admission: } \\
\text { Yes } \\
\text { Outcome: } \\
\text { Death }\end{array}$ \\
\hline $\begin{array}{l}\text { Female } \\
51 \\
\text { Hypertension; } \\
\text { DM }\end{array}$ & $\begin{array}{l}\text { COVID-19 } \\
\text { confirmation } \\
\text { test: } \\
\text { Positive rRT- } \\
\text { PCR } \\
\text { COVID-19 } \\
\text { to AD } \\
\text { latency: } \\
12 \text { days }\end{array}$ & $\begin{array}{l}\text { De novo: } \\
\text { Autoimmune } \\
\text { meningoencephalitis }\end{array}$ & $\begin{array}{l}\text { CSF high protein } \\
\text { level }\end{array}$ & $\begin{array}{l}\text { AD: Plasmapheresis } \\
\text { COVID-19: Intubation; } \\
\text { Mechanical ventilator support; } \\
\text { Azithromycin; } \\
\text { Hydroxychloroquine; Favipiravir }\end{array}$ & $\begin{array}{l}\text { Hospitalization: } \\
33 \text { days } \\
\text { ICU admission: } \\
\text { Yes } \\
\text { Outcome: } \\
\text { Favorable }\end{array}$ \\
\hline $\begin{array}{l}\text { Male } \\
55 \\
\text { Hypertension }\end{array}$ & $\begin{array}{l}\text { COVID-19 } \\
\text { confirmation } \\
\text { test: } \\
\text { Positive rRT- } \\
\text { PCR } \\
\text { COVID-19 } \\
\text { to AD } \\
\text { latency: } \\
15 \text { days }\end{array}$ & $\begin{array}{l}\text { De novo: } \\
\text { Autoimmune } \\
\text { meningoencephalitis }\end{array}$ & $\begin{array}{l}\text { CSF high protein } \\
\text { level; High serum } \\
\text { IL-6 }\end{array}$ & $\begin{array}{l}\text { AD: Plasmapheresis } \\
\text { COVID-19: Intubation; } \\
\text { Mechanical ventilator support; } \\
\text { Prone positioning; Azithromycin; } \\
\text { Hydroxychloroquine; Favipiravir }\end{array}$ & $\begin{array}{l}\text { Hospitalization: } \\
>39 \text { days } \\
\text { ICU admission: } \\
\text { Yes } \\
\text { Outcome: Not } \\
\text { reported }\end{array}$ \\
\hline $\begin{array}{l}\text { Male } \\
22 \\
\text { Autism }\end{array}$ & $\begin{array}{l}\text { COVID-19 } \\
\text { confirmation } \\
\text { test: } \\
\text { Positive rRT- } \\
\text { PCR } \\
\text { COVID-19 } \\
\text { to AD } \\
\text { latency: } \\
14 \text { days }\end{array}$ & $\begin{array}{l}\text { De novo: } \\
\text { Autoimmune } \\
\text { meningoencephalitis }\end{array}$ & $\begin{array}{l}\text { CSF high protein } \\
\text { level; High serum } \\
\text { IL-6 }\end{array}$ & $\begin{array}{l}\text { AD: Plasmapheresis } \\
\text { COVID-19: Intubation; } \\
\text { Mechanical ventilator support; } \\
\text { Prone positioning; Azithromycin; } \\
\text { Hydroxychloroquine; Favipiravir }\end{array}$ & $\begin{array}{l}\text { Hospitalization: } \\
31 \text { days } \\
\text { ICU admission: } \\
\text { Yes } \\
\text { Outcome: } \\
\text { Favorable }\end{array}$ \\
\hline
\end{tabular}

Azithromycin; Ceftriaxone; Favorable

Hydroxychloroquine; Favipiravir
COVID-19

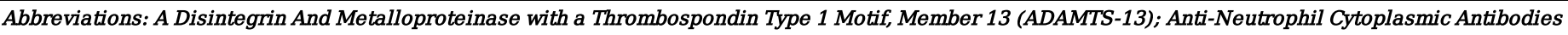

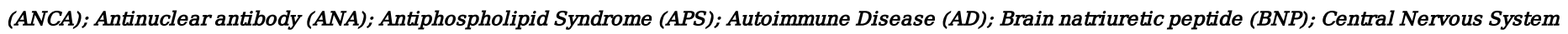

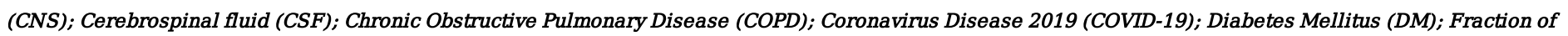

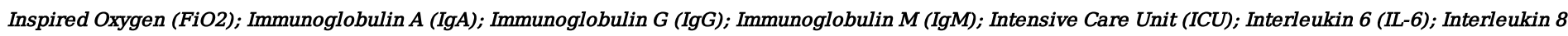

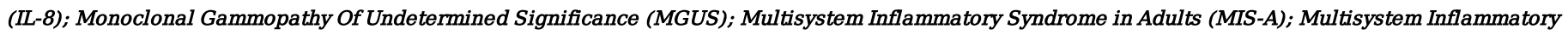

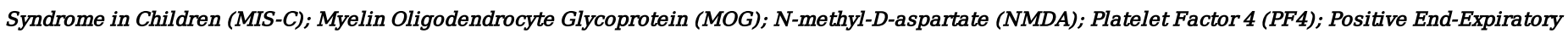

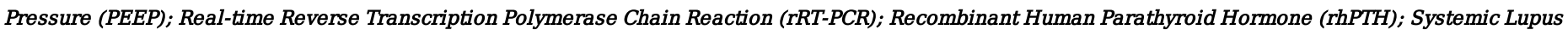
Erythematosus (SLE); Tumor necrosis factor $\alpha(T N F-\alpha$ ) 
Table 2. Total and by group summary of findings. General population and case characteristics, laboratory findings divided by areas, COVID-19 related radiologic findings and treatment, and AD-related treatment summarized with frequencies and descriptive statistics for the total and all major groups. 


\begin{tabular}{|c|c|c|c|c|c|c|c|}
\hline & & & Total & $\begin{array}{c}\text { Neurologic } \\
\mathrm{AD}\end{array}$ & Blood AD & $\begin{array}{c}\text { Vasculitis } \\
\text { AD }\end{array}$ & $\begin{array}{l}\text { Connectivitis/ } \\
\text { SLE/APS AD }\end{array}$ \\
\hline \multirow{20}{*}{$\begin{array}{l}\text { General } \\
(\mathrm{N}(\%))\end{array}$} & & $\mathrm{N}^{*}$ & 85 & 36 (42.4\%) & 15 & 19 & $6(7.1 \%)$ \\
\hline & & & $(100 \%)$ & & $(17.6 \%)$ & $(22.4 \%)$ & \\
\hline & & Age (Median) & $53(32-$ & 54 (45.25- & $53(38-65$ & $13(9-36$ & $67(50-69.25$ \\
\hline & & & 63 IQR) & $61.75 \mathrm{IQR})$ & IQR) & IQR) & IQR) \\
\hline & & Sex (N (\% Female) $)$ & 40 & $16(44.4 \%)$ & $9(60.0 \%)$ & $8(42.1 \%)$ & $3(50.0 \%)$ \\
\hline & & & $(47.1 \%)$ & & & & \\
\hline & & AD comorbidity & 23 & $6(16.7 \%)$ & $5(33.3 \%)$ & $4(21.1 \%)$ & $2(33.3 \%)$ \\
\hline & & & $(27.1 \%)$ & & & & \\
\hline & & De novo $\mathrm{AD}$ & 70 & 32 (88.9\%) & 13 & 18 & $4(66.7 \%)$ \\
\hline & & Exacerbation of AD & $(82.4 \%)$ & 4 (11.1\%) & (86.7\%) & $(94.7 \%)$ & $2(33.3 \%)$ \\
\hline & & & 18 & & $2(13.3 \%)$ & $1(5.3 \%)$ & \\
\hline & & & $(21.2 \%)$ & & & & \\
\hline & & COVID-19 to De novo AD latency in days & $12(6-$ & $12(7-15$ & $10(6.25-$ & $5(0-13$ & $25.5(12-45$ \\
\hline & & (Median) & 16 IQR) & IQR) & $15.75 \mathrm{IQR})$ & IQR) & IQR) \\
\hline & & ICU admission & 35 & $14(38.9 \%)$ & $3(20.0 \%)$ & 12 & $4(66.7 \%)$ \\
\hline & & & $(41.2 \%)$ & & & $(63.2 \%)$ & \\
\hline & Outcome & Favorable & 55 & $23(63.9 \%)$ & 13 & 11 & $1(16.7 \%)$ \\
\hline & & & $(64.7 \%)$ & & $(86.7 \%)$ & $(57.9 \%)$ & \\
\hline & & Death & 9 & 5 (13.9\%) & $1(6.7 \%)$ & $2(10.5 \%)$ & $1(16.7 \%)$ \\
\hline & & & $(10.6 \%)$ & & & & \\
\hline \multirow{42}{*}{$\begin{array}{l}\text { Laboratory findings } \\
(\mathrm{N}(\%))\end{array}$} & $\mathrm{CSF}$ & CSF high protein level & 20 & $20(55.6 \%)$ & $0(0.0 \%)$ & $0(0.0 \%)$ & $0(0.0 \%)$ \\
\hline & & & $(23.5 \%)$ & & & & \\
\hline & & CSF pleocytosis & 6 & $5(13.9 \%)$ & $0(0.0 \%)$ & $1(5.3 \%)$ & $0(0.0 \%)$ \\
\hline & & & $(7.1 \%)$ & & & & \\
\hline & & CSF albumin-cytological dissociation & 5 & $5(13.9 \%)$ & $0(0.0 \%)$ & $0(0.0 \%)$ & $0(0.0 \%)$ \\
\hline & & & $(5.9 \%)$ & & & & \\
\hline & & CSF high IgG & 5 & $5(13.9 \%)$ & $0(0.0 \%)$ & $0(0.0 \%)$ & $0(0.0 \%)$ \\
\hline & & & $(5.9 \%)$ & & & & \\
\hline & Immune markers & Anti-MOG antibodies & 1 & $1(2.8 \%)$ & $0(0.0 \%)$ & $0(0.0 \%)$ & $0(0.0 \%)$ \\
\hline & & & $(1.2 \%)$ & & & & \\
\hline & & Anti-NMDA receptor antibodies & 1 & $1(2.8 \%)$ & $0(0.0 \%)$ & $0(0.0 \%)$ & $0(0.0 \%)$ \\
\hline & & & $(1.2 \%)$ & & & & \\
\hline & & Anti-ganglioside antibodies (Asialo GM1) & 1 & $1(2.8 \%)$ & $0(0.0 \%)$ & $0(0.0 \%)$ & $0(0.0 \%)$ \\
\hline & & & $(1.2 \%)$ & & & & \\
\hline & & Anti-cardiolipin antibodies & 6 & $1(2.8 \%)$ & $0(0.0 \%)$ & $1(5.3 \%)$ & $4(66.7 \%)$ \\
\hline & & & $(7.1 \%)$ & & & & \\
\hline & & Anti-beta-2-glycoprotein I antibodies & 4 & $0(0.0 \%)$ & $0(0.0 \%)$ & $0(0.0 \%)$ & $4(66.7 \%)$ \\
\hline & & & $(4.7 \%)$ & & & & \\
\hline & & Direct Coombs Test & 4 & $0(0.0 \%)$ & $4(26.7 \%)$ & $0(0.0 \%)$ & $0(0.0 \%)$ \\
\hline & & & $(4.7 \%)$ & & & & \\
\hline & & High cold agglutinin titers & 2 & $0(0.0 \%)$ & $2(13.3 \%)$ & $0(0.0 \%)$ & $0(0.0 \%)$ \\
\hline & & & $(2.4 \%)$ & & & & \\
\hline & & Anti-ADAMTS-13 inhibitory antibodies & 1 & $0(0.0 \%)$ & $1(6.7 \%)$ & $0(0.0 \%)$ & $0(0.0 \%)$ \\
\hline & & & $(1.2 \%)$ & & & & \\
\hline & & Anti-platelet antibodies & 1 & $0(0.0 \%)$ & $1(6.7 \%)$ & $0(0.0 \%)$ & $0(0.0 \%)$ \\
\hline & & & $(1.2 \%)$ & & & & \\
\hline & & Anti-platelet factor 4 /heparin antibodies & 1 & $0(0.0 \%)$ & $1(6.7 \%)$ & $0(0.0 \%)$ & $0(0.0 \%)$ \\
\hline & & & $(1.2 \%)$ & & & & \\
\hline & & ANA & 3 & $0(0.0 \%)$ & $1(6.7 \%)$ & $1(5.3 \%)$ & $0(0.0 \%)$ \\
\hline & & & $(3.5 \%)$ & & & & \\
\hline & & High Complement & 1 & $0(0.0 \%)$ & $0(0.0 \%)$ & $1(5.3 \%)$ & $0(0.0 \%)$ \\
\hline & & & $(1.2 \%)$ & & & & \\
\hline & & Low complement & 1 & $0(0.0 \%)$ & $0(0.0 \%)$ & $1(5.3 \%)$ & $0(0.0 \%)$ \\
\hline & & & $(1.2 \%)$ & & & & \\
\hline & & High IgA serum levels & 1 & $0(0.0 \%)$ & $0(0.0 \%)$ & $1(5.3 \%)$ & $0(0.0 \%)$ \\
\hline & & & $(1.2 \%)$ & & & & \\
\hline & & ANCA & 1 & $0(0.0 \%)$ & $0(0.0 \%)$ & $1(5.3 \%)$ & $0(0.0 \%)$ \\
\hline & & & $(1.2 \%)$ & & & & \\
\hline & & Anti-Ro/SSA & 1 & $0(0.0 \%)$ & $0(0.0 \%)$ & $1(5.3 \%)$ & $0(0.0 \%)$ \\
\hline & & & $(1.2 \%)$ & & & & \\
\hline & Hemostasis sy & High d-dimers & 32 & $10(27.8 \%)$ & $5(33.3 \%)$ & 13 & $4(66.7 \%)$ \\
\hline & markers & & $(37.6 \%)$ & & & $(68.4 \%)$ & \\
\hline
\end{tabular}

Page 29/33 


\begin{tabular}{|c|c|c|c|c|c|c|c|}
\hline & & \multirow[t]{2}{*}{ High fibrinogen } & \multirow{2}{*}{$\begin{array}{r}13 \\
(15.3 \%)\end{array}$} & \multirow[t]{2}{*}{$2(5.6 \%)$} & \multirow[t]{2}{*}{$3(20.0 \%)$} & \multirow[t]{2}{*}{$5(26.3 \%)$} & \multirow[t]{2}{*}{$3(50.0 \%)$} \\
\hline & & & & & & & \\
\hline & & INR & 7 & $0(0.0 \%)$ & $0(0.0 \%)$ & 7 (36.8\%) & $0(0.0 \%)$ \\
\hline & & & $(8.2 \%)$ & & & & \\
\hline & & High prothrombin time & 6 & $0(0.0 \%)$ & $0(0.0 \%)$ & 3 (15.8\%) & 3 (50.0\%) \\
\hline & & & $(7.1 \%)$ & & & & \\
\hline & & High partial thromboplastin time (aPTT) & 3 & $0(0.0 \%)$ & $0(0.0 \%)$ & $0(0.0 \%)$ & 3 (50.0\%) \\
\hline & & & $(3.5 \%)$ & & & & \\
\hline & Inflammatory markers & High c-reactive protein & 49 & $18(50.0 \%)$ & $5(33.3 \%)$ & 17 & $4(66.7 \%)$ \\
\hline & & & $(57.6 \%)$ & & & $(89.5 \%)$ & \\
\hline & & High procalcitonin & 12 & $0(0.0 \%)$ & $0(0.0 \%)$ & 12 & $0(0.0 \%)$ \\
\hline & & & $(14.1 \%)$ & & & $(63.2 \%)$ & \\
\hline & & High ferritin & 25 & 10 (27.8\%) & $3(20.0 \%)$ & 10 & $1(16.7 \%)$ \\
\hline & & & $(29.4 \%)$ & & & $(52.6 \%)$ & \\
\hline & & High lactate dehydrogenase & 23 & 7 (19.4\%) & $5(33.3 \%)$ & $9(47.4 \%)$ & $2(33.3 \%)$ \\
\hline & & & $(27.1 \%)$ & & & & \\
\hline & & High erythrocyte sedimentation rate & 14 & $5(13.9 \%)$ & $0(0.0 \%)$ & $8(42.1 \%)$ & $0(0.0 \%)$ \\
\hline & & & (16.5\%) & & & & \\
\hline & & High serum IL-6 & 14 & 5 (13.9\%) & $2(13.3 \%)$ & $6(31.6 \%)$ & $1(16.7 \%)$ \\
\hline & & & $(16.5 \%)$ & & & & \\
\hline & & High serum IL-8 & 5 & $0(0.0 \%)$ & $0(0.0 \%)$ & 5 (26.3\%) & $0(0.0 \%)$ \\
\hline & & & $(5.9 \%)$ & & & & \\
\hline & & High serum TNF- $\alpha$ & 5 & $0(0.0 \%)$ & $0(0.0 \%)$ & $5(26.3 \%)$ & $0(0.0 \%)$ \\
\hline & & & $(5.9 \%)$ & & & & \\
\hline & & High troponins levels & 9 & $0(0.0 \%)$ & $0(0.0 \%)$ & 7 (36.8\%) & $2(33.3 \%)$ \\
\hline & & & $(10.6 \%)$ & & & & \\
\hline & & High myogloblin level & 1 & $0(0.0 \%)$ & $0(0.0 \%)$ & $1(5.3 \%)$ & $0(0.0 \%)$ \\
\hline & & & $(1.2 \%)$ & & & & \\
\hline & Other general & Anemia & 22 & $3(8.3 \%)$ & $8(53.3 \%)$ & $8(42.1 \%)$ & $3(50.0 \%)$ \\
\hline & laboratory & & (25.9\%) & & & & \\
\hline & measurements & Reticulocytosis & 4 & $0(0.0 \%)$ & $4(26.7 \%)$ & $0(0.0 \%)$ & $0(0.0 \%)$ \\
\hline & & & $(4.7 \%)$ & & & & \\
\hline & & Leukocytosis & 29 & 11 (30.6\%) & 4 (26.7\%) & 11 & $3(50.0 \%)$ \\
\hline & & & (34.1\%) & & & $(57.9 \%)$ & \\
\hline & & Leukopenia & 2 & $0(0.0 \%)$ & $0(0.0 \%)$ & $0(0.0 \%)$ & $2(33.3 \%)$ \\
\hline & & & $(2.4 \%)$ & & & & \\
\hline & & Lymphocytopenia & 36 & 7 (19.4\%) & $9(60.0 \%)$ & 14 & $4(66.7 \%)$ \\
\hline & & & $(42.4 \%)$ & & & $(73.7 \%)$ & \\
\hline & & Thrombocytopenia & 31 & 6 (16.7\%) & 12 & $9(47.4 \%)$ & $4(66.7 \%)$ \\
\hline & & & (36.5\%) & & (80.0\%) & & \\
\hline & & Thrombocytosis & 3 & $3(8.3 \%)$ & $0(0.0 \%)$ & $0(0.0 \%)$ & $0(0.0 \%)$ \\
\hline & & & $(3.5 \%)$ & & & & \\
\hline & & Hyponatremia & 8 & $1(2.8 \%)$ & $0(0.0 \%)$ & 7 (36.8\%) & $0(0.0 \%)$ \\
\hline & & & $(9.4 \%)$ & & & & \\
\hline & & High alanine aminotransferase (ALT) & 17 & $5(13.9 \%)$ & $1(6.7 \%)$ & 10 & $0(0.0 \%)$ \\
\hline & & & $(20.0 \%)$ & & & $(52.6 \%)$ & \\
\hline & & High aspartate aminotransferase (AST) & 13 & $6(16.7 \%)$ & $1(6.7 \%)$ & $5(26.3 \%)$ & $0(0.0 \%)$ \\
\hline & & & $(15.3 \%)$ & & & & \\
\hline & & High gamma-glutamyl transferase & 2 & $1(2.8 \%)$ & $0(0.0 \%)$ & $1(5.3 \%)$ & $0(0.0 \%)$ \\
\hline & & & $(2.4 \%)$ & & & & \\
\hline & & Direct hyperbilirubinemia & 2 & $0(0.0 \%)$ & $0(0.0 \%)$ & $2(10.5 \%)$ & $0(0.0 \%)$ \\
\hline & & & $(2.4 \%)$ & & & & \\
\hline & & Indirect hyperbilirubinemia & 3 & $0(0.0 \%)$ & $3(20.0 \%)$ & $0(0.0 \%)$ & $0(0.0 \%)$ \\
\hline & & & $(3.5 \%)$ & & & & \\
\hline & & Hypoalbuminemia & 12 & $1(2.8 \%)$ & $0(0.0 \%)$ & $8(42.1 \%)$ & $3(50.0 \%)$ \\
\hline & & & $(14.1 \%)$ & & & & \\
\hline COVID-19 related & & Normal & 9 & $2(5.6 \%)$ & $2(13.3 \%)$ & $3(15.8 \%)$ & $0(0.0 \%)$ \\
\hline radiologic findings & & & $(10.6 \%)$ & & & & \\
\hline$(\mathrm{N}(\%))$ & & Bilateral ground-glass opacities & 34 & $17(47.2 \%)$ & $4(26.7 \%)$ & $3(15.8 \%)$ & $4(66.7 \%)$ \\
\hline & & & $(40.0 \%)$ & & & & \\
\hline & & Bilateral pulmonary infiltrates & 12 & $3(8.3 \%)$ & $3(20.0 \%)$ & $2(10.5 \%)$ & $3(50.0 \%)$ \\
\hline & & & $(14.1 \%)$ & & & & \\
\hline & & Diffused consolidations & 11 & $8(22.2 \%)$ & $2(13.3 \%)$ & $0(0.0 \%)$ & $1(16.7 \%)$ \\
\hline & & & $(12.4 \%)$ & & & & \\
\hline
\end{tabular}


Other tests

(N)
Nerve conduction studies - GBS

Skin biopsy - leukocytoclastic vasculitis

Bone marrow aspirate - normal cellularity with an increased megakaryocyte count

\section{$\mathrm{AD}$ treatment} (N (\%))

None
Immunoglobulin

Corticosteroids

Antibiotic prophylaxis

Plasma exchange therapies

Supportive therapy

Transfusion

Immunomodulator

Shock therapy

Anticoagulant

Other

Acetylsalicylic acid

Anticonvulsant

Thrombopoietin pathway therapy

Cirurgy

Antiviric prophylaxis

Antipsychotic

Antifibrinolytic

NSAID

\section{COVID-19 treatment}

(N (\%))

None
Supportive therapy
Hydroxychloroquine
Antiviric therapy
Antibiotic therapy
Other

12
$(14.1 \%)$

$1212(33.3 \%) \quad 0(0.0 \%) \quad 0(0.0 \%) \quad 0(0.0 \%)$

3

(3.5\%)

2

$(2.4 \%)$

$13.4 \%)$

(15.3\%)

42

(49.4\%)

35

(41.2\%)

16

(18.8\%)

13

(15.3\%)

12

(14.1\%)

12

(14.1\%)

9

(10.6\%)

8

(9.4\%)

6

(7.1\%)

5

(5.9\%)

5

(5.9\%)

3

(3.5\%)

3

(3.5\%)

3

(3.5\%)

2

(2.4\%)

1

(1.2\%)

1

(1.2\%)

1

$(1.2 \%)$

26

(30.6\%)

40

(47.1\%)

33
$(38.8 \%)$

28
$(32.9 \%)$
31

31
$6.5 \%)$

16

$0(0.0 \%) \quad 0(0.0 \%) \quad 3(15.8 \%) \quad 0(0.0 \%)$

$0(0.0 \%) \quad 2(13.3 \%) \quad 0(0.0 \%) \quad 0(0.0 \%)$

$3(8.3 \%) \quad 0(0.0 \%) \quad 2(10.5 \%) \quad 3(50.0 \%)$

$19(52.8 \%) \quad 10 \quad 11 \quad 2(33.3 \%)$

(66.7\%) (57.9\%)

$\begin{array}{llll}(30.6 \%) & 12 & 10 & 1(16.7 \%)\end{array}$

$(80.0 \%) \quad(52.6 \%)$

$3(8.3 \%) \quad 0(0.0 \%) \quad 13$

(68.4\%)

$10(27.8 \%) \quad 1(6.7 \%) \quad 1(5.3 \%)$

$0(0.0 \%)$

$1(16.7 \%)$

$4(11.1 \%) \quad 0(0.0 \%) \quad 7(36.8 \%) \quad 0(0.0 \%)$

$0(0.0 \%) \quad 11 \quad 0(0.0 \%) \quad 1(16.7 \%)$

(73.3\%)

$1(2.8 \%) \quad 1(6.7 \%) \quad 5(26.3 \%) \quad 0(0.0 \%)$

$0(0.0 \%) \quad 0(0.0 \%) \quad 8(42.1 \%) \quad 0(0.0 \%)$

$0(0.0 \%) \quad 1(6.7 \%) \quad 3(15.8 \%) \quad 1(16.7 \%)$

$1(2.8 \%) \quad 1(6.7 \%) \quad 1(5.3 \%) \quad 0(0.0 \%)$

$0(0.0 \%) \quad 0(0.0 \%) \quad 4(21.1 \%) \quad 1(16.7 \%)$

$3(8.3 \%) \quad 0(0.0 \%) \quad 0(0.0 \%) \quad 0(0.0 \%)$

$0(0.0 \%) \quad 2(13.3 \%) \quad 0(0.0 \%) \quad 1(16.7 \%)$

$0(0.0 \%) \quad 1(6.7 \%) \quad 2(10.5 \%) \quad 0(0.0 \%)$

$2(5.6 \%) \quad 0(0.0 \%) \quad 0(0.0 \%) \quad 0(0.0 \%)$

$1(2.8 \%) \quad 0(0.0 \%) \quad 0(0.0 \%) \quad 0(0.0 \%)$

$0(0.0 \%) \quad 1(6.7 \%) \quad 0(0.0 \%) \quad 0(0.0 \%)$

$0(0.0 \%) \quad 0(0.0 \%) \quad 1(5.3 \%) \quad 0(0.0 \%)$

$8(22.2 \%) \quad 4(26.7 \%) \quad 10 \quad 1(16.7 \%)$

(52.6\%)

$21(58.3 \%) \quad 6(40.0 \%) \quad 7(36.8 \%) \quad 3(50.0 \%)$

$20(55.6 \%) \quad 4(26.7 \%) \quad 4(21.1 \%) \quad 0(0.0 \%)$

$17(47.2 \%) \quad 4(26.7 \%) \quad 0(0.0 \%) \quad 4(66.7 \%)$

$16(44.4 \%) \quad 5(33.3 \%) \quad 4(21.1 \%) \quad 4(66.7 \%)$

$4(11.1 \%) \quad 5(33.3 \%) \quad 3(15.8 \%) \quad 1(16.7 \%)$

$(18.8 \%)$

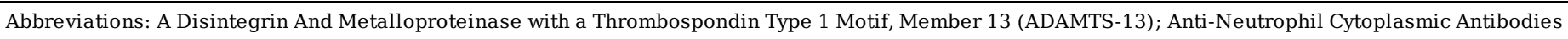

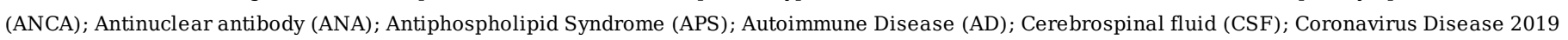

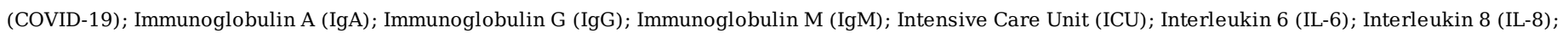

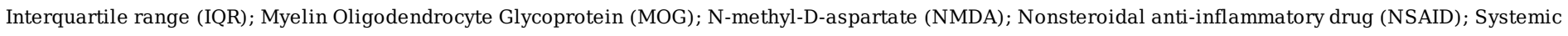
Lupus Erythematosus (SLE); Tumor necrosis factor $\alpha$ (TNF- $\alpha$ )

*In this case percentages refer to the 85 total population. 


\section{Figures}

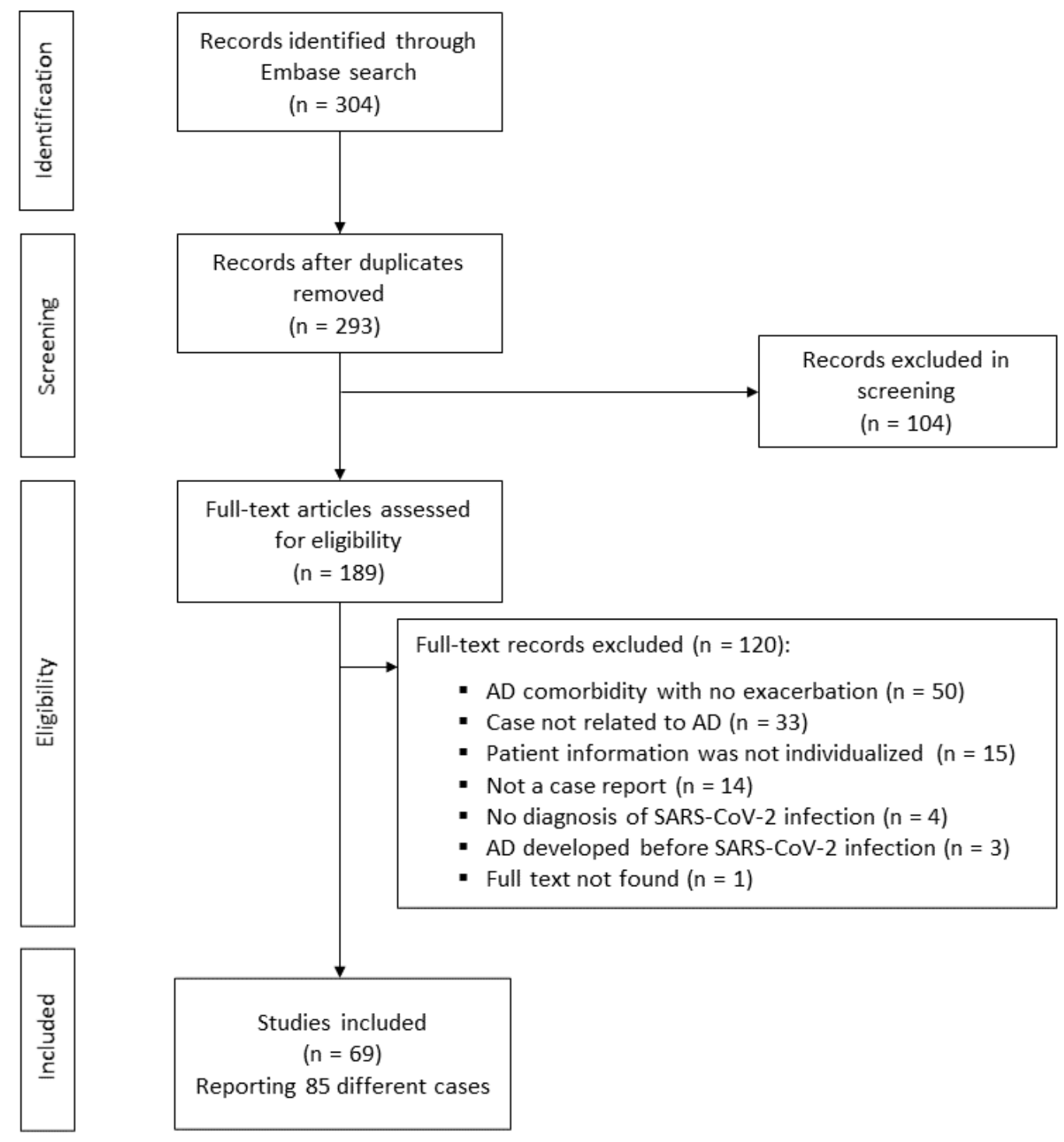

\section{Figure 1}

PRISMA flowchart. Search results and study selection process by stage according to the PRISMA statement guidelines. 


\section{JBI Critical Appraisal Checklist}

1. Patient's demographic characteristics

2. Patient's history

3. Current clinical condition

4. Diagnostic tests and results

5. Intervention or treatment

6. Post-intervention clinical condition

7. Adverse or unanticipated events

8. Provides takeaway lessons

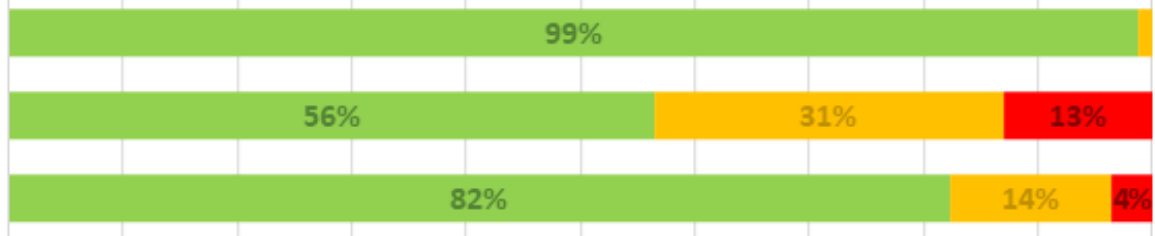

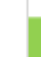
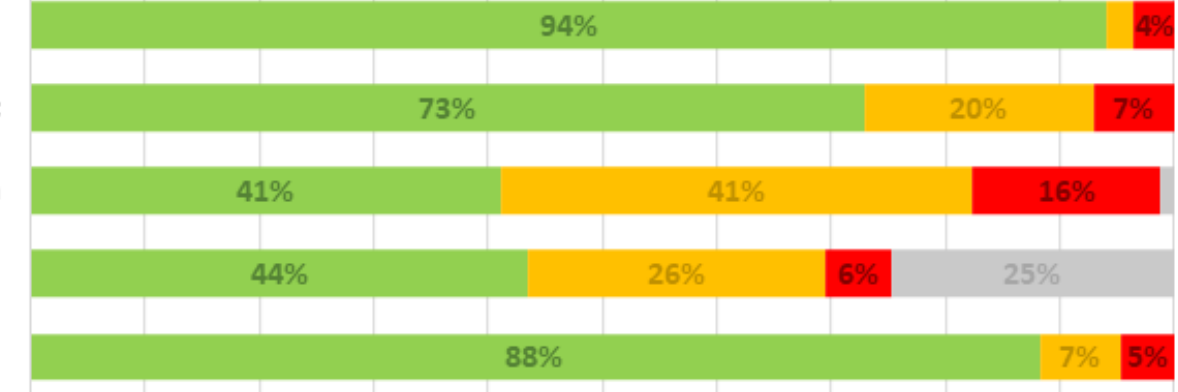

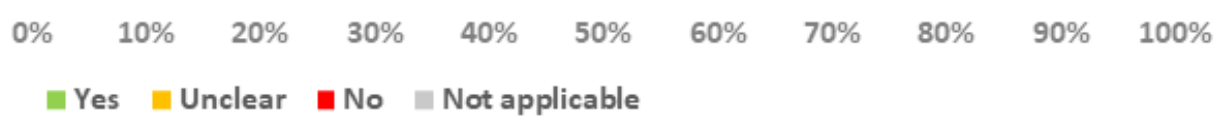

Figure 2

JBI Critical Appraisal Checklist. Summary of results for each of the JBI Critical Appraisal Checklist for Case Reports quality domains.

\section{Supplementary Files}

This is a list of supplementary files associated with this preprint. Click to download.

- Additionalfile1.docx

- Additionalfile2.docx

- Additionalfile3.docx 